\title{
PERSPECTIVES ON INCLUSION IN THE GENERAL EDUCATION CLASSROOM
}

\author{
A Dissertation \\ presented to \\ the Faculty of the Graduate School \\ at the University of Missouri-Columbia \\ In Partial Fulfillment \\ of the Requirements for the Degree \\ Doctor of Education \\ by \\ KIMBERLY KESLER \\ Dr. Paul Watkins, Dissertation Supervisor \\ May 2019
}


The undersigned, appointed by the dean of the Graduate School, have examined the Dissertation entitled

Perspectives On Inclusion In The General Education Classroom

Presented by Kimberly Kesler,

A candidate for the degree of Doctor of Educational Leadership

And hereby certify that, in their opinion, it is worthy of acceptance.

Dr. Paul Watkins, Chair

Dr. David Stader

Dr. William Bratberg

Dr. Sharon Gunn 


\section{Acknowledgements}

I am so grateful to the many people who have helped me through this process. Thank you to all my committee members, Dr. Paul Watkins, Dr. David Stader, Dr. William Bratberg, and Dr. Sharon Gunn, for your input and guidance during the progression of this dissertation. I would especially like to thank Dr. Paul Watkins, the chair of my committee. Thank you for your continuous help even in your retirement.

I would like to thank my Cohort 8 classmates. Thank you for your collaboration and support. Thank you for being a sounding board for thoughts and ideas. Thank you for helping me develop and grow.

Thank you to the participants in this case study. Without your help and support, none of this would be possible. I am grateful for your leadership and your willingness to be change agents in the field of education. 
Table of Contents

ACKNOWLEDGEMENTS ................................................ ii

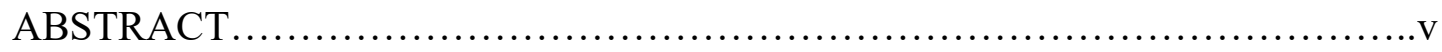

Chapter

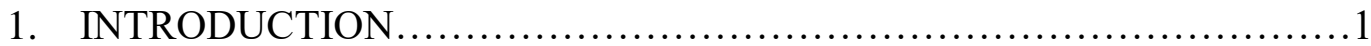

Problem Statement

Purpose of Study

Research Questions

Conceptual Framework

Significance of Study

Key Terms

Limitations

Assumptions

2. REVIEW OF LITERATURE.

16

Conceptual Framework

Review of Research

Summary

3. METHODOLOGY

Research Questions

Setting

Participants and Sampling Procedures

Data Collection

Data Analysis 
Trustworthiness

Limitations and Assumptions

Summary

4. RESEARCH FINDINGS

46

Introduction

Findings

Conclusion

5. CONLCUSION, DISCUSSION, AND SUGGESTIONS FOR FUTURE

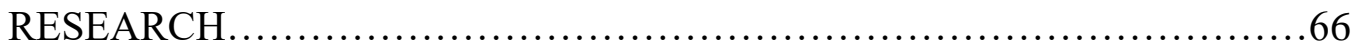

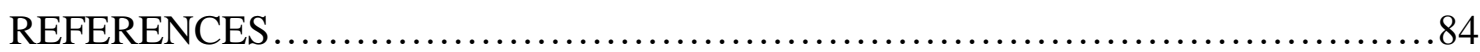

APPENDIX

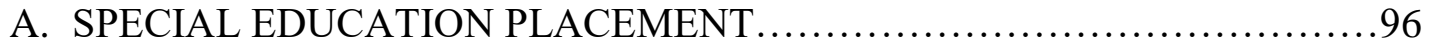

B. TYPES OF RESOURCES FOR EXTRA SUPPORT ........................97

C. CLASSROOM ACCOMODATIONS AND MODIFICATIONS ...............98

D. INTERVIEW PROTOCOL FOR THE CLASSROOM EDUCATOR..........103

E. INTERVIEW PROTOCOL FOR THE SCHOOL DISTRICT

ADMINISTRATOR..................................................... 106

F. PARTICIPANT REQUEST ............................................. 109

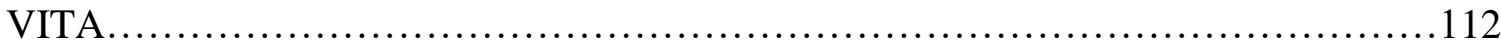




\begin{abstract}
The focus of this case study involves inclusion of students with disabilities in the general education classroom. The emphasis is on $7^{\text {th }}-12^{\text {th }}$ grade general education teachers and administrators' perspectives regarding inclusion. Laws, such as Individuals with Disabilities Education Act and Every Student Succeeds Act, ensure all students receive an appropriate education. Inclusion would provide instruction for students with disabilities in the general education environment to the maximum extent possible. This appropriate education must be received in the least restrictive environment. Students with disabilities should receive appropriate accommodations and modifications in the general education classroom in order to be successful. The IEP team, which consists of general education teachers, special education teachers, administrators and parents, determine the appropriate placement for individual students.

This case study is centered around Social Justice Theory. Under Social Justice Theory all students have equal access to instruction and resources in the learning environment. Students are supported and held to high expectations. Leaders should create a learning environment in which all students can be successful.

This case study focuses on teachers and administrators of grades $7^{\text {th }}-12^{\text {th }}$. The researcher chose these grade levels because there seems to be difficulty implementing accommodations and modifications for students with disabilities in these grades in the school district under study. This difficulty could be due to the short amount of time teachers have students. Each class period is 50 minutes long. Students begin receiving credits for graduation in the $9^{\text {th }}$ grade. How assignments are modified may affect the content learn by students. The amount of time students with disabilities take to learn
\end{abstract}


content and the actual content they are learning may be why general education teachers struggle with inclusion of students with disabilities in the classroom.

The elementary principal was included in this case study because this position is part of the district administration team. The district administration team is the decisionmaking body for the school district. The researcher included the elementary principal for this reason. 


\section{Perspectives on Inclusion in the General Education Classroom}

\section{Chapter 1}

Current policies, such as Individuals with Disabilities Education Act (IDEA), mandate students with disabilities have access to free, appropriate public education and be educated in the least restrictive environment (McGovern, 2015, p. 117). Inclusion requires students with disabilities to receive instruction in the general education classroom while given essential tools and supports they need to be successful (Fuchs, 2009-2010; Lambert, 67). Buli-Holmberg and Jeyaprathaban (2016), state inclusion means "full-time placement" in the general education classroom while giving students with disabilities the appropriate accommodations and modifications needed to be successful (p. 119). Braunsteiner and Mariano-Lapidus (2014) take the definition of inclusion one step further and say students with disabilities should "fully participate and contribute in all aspects of life and culture, without restriction, or threat of marginalization creates no such barrier” (p. 37). In contrast, LeDoux, Graves, and Burt (2012) argues students with disabilities may be pulled from the general education classroom when learning cannot be achieved (p. 20). According to Dudley-Marling and Burns (2014), most students with disabilities are receiving instruction in the general education classroom during the educational day (p. 15). LeDoux, Graves, and Burt (2012) state that in "2007-2008 about $13 \%$ of the national public-school enrollment received special education services and of this percentage, $94.6 \%$ of the students with disabilities spend part of their day in the general education setting" (p.21).

When educating students with disabilities, it is important to place students in the least restrictive environment. IDEA 2004 states students with disabilities should be 
included with non-disabled peers "to the maximum extent appropriate" (Wright and Wright, 2016, p. 23, 72; LeDoux, Graves, Burt, 2012, p. 20; Lambert, p. 67; Jorgensen and Lambert, 2012, p. 23; Dudley-Marling and Burns, 2014, p. 17). Few options are available when deciding placement for students with disabilities. The options that are available depend on the needs of each student. Students who receive most of their instruction with non-disabled peers are placed inside the general education class $80 \%$ or more of the day. Students who need more specialized instruction are placed inside the general education class no more than $79 \%$ of the day and no less than $40 \%$ of the day. Students whose disabilities require self-containment are placed inside the general education class less than $40 \%$ of the day. Additional placements include residential facilities, separate schools, or home (DESE.mo.gov, 2018) (see Appendix A for special education placement). Deciding placement for students with disabilities is a decision that should be made by all stakeholders. General education teachers, special education teachers, administrators, and parents should all be involved in the placement decision. Students with special needs who receive instruction in the general education classroom should be afforded accommodations and modifications as outlined in their Individualized Education Program (IEP). Students can be given accommodations when accessing the general education curriculum. Accommodations do not change the content for a student. Accommodations are changes to the time frame given to a student to complete an assignment or test, the setting in which a student completes assignments or tests, or the way a student responds to assignments or tests. However, modifications are changes to the actual content of material for students. Students may only finish part of the 
assignment or test or the assignment or test given may be at a lower difficulty level than non-disabled peers.

Laws such as the Rehabilitation Act of 1973, Section 504, Individuals with Disabilities Education Act (IDEA) and the No Child Left Behind Act of 2001 (NCLB) and most recently Every Student Succeeds Act (ESSA) have been enacted to ensure that all students receive an appropriate education including general education instruction. Individuals who participate in education studies need to be familiar with the special education process. Pre-service teachers should be exposed and equipped with the tools needed to ensure all student have access to the best education possible (Leatherman, 2007, p. 595). Teacher attitudes play a significant role in whether students with disabilities will be successful in the general education classroom. Teacher's opinions and outlooks play an important role in teaching students with disabilities (Fuchs, 2009-2010, p.30-31; Braunsteiner and Mariano-Lapidus, 2014, p. 33-35). Studies have sounded the alarm that teachers are not prepared or equipped to teach students with disabilities in the general education classroom setting (LeDoux, Graves, Burt, 2012, p. 21; Taylor and Ringlaben, 2012, p. 16-17; Fuchs, 2009-2010, p. 30, 32-34).

This case study will examine the perceptions of general education teachers and administrators in grades 7-12 and inclusion of students with disabilities in the general education classroom setting. The school district under study has $18 \%$ of its total population receiving special education services. Of those students receiving special education services, $95 \%$ of them receive services in the general education classroom. As this percentage shows, the general education classroom teacher must be prepared to teach students with disabilities. The students in the school district range from speech 
disabilities to cognitive disabilities. Some students have behavior disorders as well. The district currently has three special education teachers: two elementary and one teacher for junior high and high school.

\section{Statement of the Problem}

Fuchs revealed, " $75 \%$ of teachers who participate in her study believed inclusion would not be successful and were not in favor of inclusion" (p. 30). With current laws such as IDEA and ESSA, inclusion is no longer a choice for school districts. Inclusion is mandated by law. How teachers feel about inclusion dictates how successful students with disabilities will perform academically in their classrooms (Fuchs, 2010, p. 30; Taylor \& Ringlaben, 2012, p. 17). Additional research found that teachers were not prepared to teach students with disabilities (LeDoux, Graves, \& Burt, 2012, p. 26; Braunsteiner \& Mariano-Lapidus, 2014, p. 35; Taylor \& Ringlaben, 2012, p. 17).

School districts need to provide the necessary resources and support for both general education teachers and special education teachers to safeguard the success of inclusion of students with disabilities in the general education classroom. Programs available to pre-service teachers are lacking. Fuchs (2010) states education programs provide a limited number of courses and training for general education teachers to effectively instruct students with disabilities in their classroom (p. 32). Lambert (n.d.) states when teachers are trained, their perception regarding teaching students with disabilities is more positive (p. 70).

Dudley-Marling and Burns (2014) point out that before the "Education for All Children Act only one in five students with disabilities were educated in public schools" (p. 14). Educators have the mindset that "inclusion of students into the regular education setting would take too much of the teacher's attention and have detrimental effects for 
students without disabilities" (Dudley-Marling and Burns, 2014, p. 16). Additional research shows teachers feel that planning and instructing students with disabilities will take away learning for non-disabled students (Braunsteiner \& Mariano-Lapidus, 2014, p. 35; LeDoux, Graves, \& Burt, 2012, p. 25).

The support and training general educations teachers receive regarding students with disabilities before entering the classroom is limited. Fuchs (2010) found some teachers were only required to take one course regarding special education and professional development was not offered frequently in their school district (p. 33-34). Also, Hadadian and Chaing (2007) found proper training for students with disabilities would be useful for preservice teachers (p. 106). Bender, Vail, and Scott (1995), as stated in Hadadian and Chaing (2007), discovered "there was a positive relationship between the attitudes of teachers and the number of courses taken in teaching students with disabilities" (p. 106). These positive relationships can be linked to improved achievement both in and outside of the general education setting creating an environment in which all students succeed.

Collaboration between the general education teacher and the special education teacher is a necessary part of training and support (Shippen, Crites, Houchins, Ramsey \& Simon, 2005, p.00; LeDoux, Graves, \& Burt, 2012, p. 24). This collaboration would provide an opportunity for the general education teachers to ask about issues concerning certain student diagnoses and gain knowledge regarding instructional strategies that can be used in the general education classroom during instruction (Buli-Holmberg \& Jeyaprathaban, 2016, p. 121). 
The education of students with disabilities continues to improve. It is important teachers have the knowledge needed to create an environment in which all students can learn. Providing additional opportunities for teachers to learn strategies needed to teach students with disabilities will foster an environment that allows for success.

\section{Purpose of the Study}

The purpose of this qualitative case study is to discover the general education teacher's and building administrator's perspective regarding instructing students with disabilities in the general education classroom in grades 7-12. Classroom teachers of junior high and high school students in the school district under study are uncertain how the accommodations and modifications outlined in student Individualized Education Programs (IEP's) work in the general classroom setting. Teachers not familiar with strategies or resources available to help during instruction, can cause them uncertainty in providing students with disabilities instruction in their classroom. This uncertainty can cause problems for general education classroom teachers and the special education teachers who collaborate regarding needs of students.

In addition to teacher perceptions, the theory behind inclusion will be examined. Current inclusion policies, such as Free Appropriate Public Education (FAPE) and Every Student Succeeds Act (ESSA), mandate students with disabilities be incorporated into the general education classroom to the fullest degree possible based on student needs. Free Appropriate Public Education outlines four areas to which school districts must adhere to. First, students with disabilities are provided services from their school district, and the parent will not endure any costs. Second, students must be allowed access to educational standards of the school district. Third, preschool students, elementary students, and secondary students are included under FAPE. Fourth, student individual education 
programs (IEP) must be met (DESE.mo.gov, 2018). ESSA aims to provide all students a chance to receive a "fair and equitable high-quality education" and "to close educational achievement gaps" (DESE.mo.gov, 2018).

According to Murray (2010), "ninety percent of teachers in preparation programs are mostly White, middle class, and from non-urban backgrounds" (p. 48). Information gathered from teacher interviews will help to determine the general perception teachers have toward inclusion. Understanding one's own biases is key to the success of inclusion of students with disabilities.

Teacher interviews will also provide the researcher with information regarding teacher confidence in teaching students with disabilities. Obstacles for students with disabilities in the general education classroom will be discussed. In addition, teachers will be asked what they perceive to be their role for teaching all students. How do teachers foster an environment that allows for diversity? The researcher will gather information regarding what support the teachers have from other colleagues and administrators. Where do teachers turn when they are having difficulty providing accommodations and modifications for students with disabilities?

Administrators must create a school environment that fosters the idea of inclusion for students with disabilities. Ryan (2006) articulates the success of inclusion "depends on the way in which leadership is conceived" (p. 7). Teachers must believe in the idea of inclusion in order for inclusion to be successful. The researcher will interview building administrators to get their perspective on how they support learning for all students. Administrators will be asked to define their role in facilitating inclusion of students with disabilities in the school district. Administrators will be asked to define their role in 
supporting staff when including students with disabilities in the general education classroom. The researcher will gather administrators' thoughts to see if teacher training is adequate and whether or not they see this training implemented in the classroom. Administrators' perceptions on being leaders within the school district versus being administrators will be considered during the interview. According to Cambron-McCabe and McCarthy (2005), administrators may have difficulty “shifting its mental model of what it means to be a school leader rather than a school administrator” (p. 209).

\section{Research Questions}

RQ1: What are the perceptions of $7-12^{\text {th }}$ grade teachers regarding inclusion of students with special needs in the general education classroom setting?

RQ2: What do $7^{\text {th }}-12^{\text {th }}$ grade teachers perceive to be the obstacles to inclusion of students with special needs?

RQ3: How do $7^{\text {th }}-12^{\text {th }}$ grade teachers understand their responsibility for teaching all students?

RQ4: How do administrators perceive their role in facilitating teacher training and resources for partial inclusion and full inclusion of special needs services?

RQ5: How do administrators foster an environment that allows students with disabilities to be successful?

\section{Conceptual Framework}

When thinking about an educational environment, school districts must adopt a mentality that includes educating all students. The social justice theory is a framework that provides education through the lens of educating the whole student. The notion behind social justice includes equality, tolerance, respect, and fairness (Bursa \& Ersoy, 2016, p. 326). Ryan (2006) adds "Most commentators on social justice, though, concede 
that it is about legitimacy, fairness and welfare" (p. 5). These are qualities all students should experience.

Murray (2010) outlines three areas to support social justice (p. 48). These areas include understanding one's thinking, creating a leadership team, and building sincere relationships with the community (Murry, 2010, p. 49). In order to create an environment that supports social justice, the participants of a school district must be aware of their prejudices and biases (Murray, 2010, p. 48). McKenzie and Scheurich (2004) explain four equity traps when teaching students of diversity: A deficit view (p. 607), racial erasure (p. 613), avoidance and employment of the gaze (p. 619), and paralogical beliefs and behaviors (p. 624). Equity traps, as defined by McKenzie and Scheurich (2004), are a way of thinking or preconceived ideas that causes educators to doubt success of a learner (p. 602). It is important for school teachers and administrators to understand their outlooks and views and how these lend to social justice.

Murray (2010) advises creating an Equity Leadership Team to study the aspects of the school environment (p. 49). This leadership team should study aspects of the school environment which include academic achievement, dropout rates, and discipline referrals (Murray, 2010, p. 49). "Social Justice will be achieved when those who are disadvantaged or marginalized are included in a meaningful way" (Ryan, 2006, p. 6). By examining school information, disproportionately among subgroups can be identified (Murray, 2010, p. 49). As part of a leadership team, Cambron-McCabe and McCarthy (2005) explain leaders must have expert knowledge in instructional practices and curriculum in order to provide social justice for all learners (p. 209). Social justice provides an "opportunity to reconsider what it means to lead in schools where student 
learning, rather that the management of daily operations, is the heart of the work" (Cambron-McCabe and McCarthy, 2005, p. 209).

"Building genuine relationships within the community of a school district is vital in helping educators promote social justice values" (Murray, 2010, p. 49). Involving the community and developing relationships with community members allows teachers and school leaders to develop their understanding of student culture. This understanding will facilitate an environment of social justice in the school district. McKenzie and Scheurich (2004), add to remove a deficit thinking approach, school personnel should get to know their students, student families, and communities on a personal level (p. 609).

\section{Significance of the Study}

Once completed, the results from this case study can be used to provide information for general education teachers and administrators on how to improve instruction for students with disabilities in the general education classroom setting. When the school district understands the teacher perspective of instructing students with disabilities, they will be able to provide the needed support and training on a continual basis.

The results provided by this case study will enhance the knowledge of special education law for general education classroom teachers. The results of this case study may help to enhance their understanding of the importance of accommodations and modifications outlined in student IEP's. General education teachers will have a better understanding of the law and how it affects them.

This case study will provide the school district with information regarding necessary resources and/or supports needed for general education teachers to deliver instruction to students with disabilities. The school district will be able to provide 
opportunities necessary to warrant student success, as well as, teacher satisfaction. The teachers and administrators can use the information provided by this case study to work together to solve current issues regarding the delivery of instruction to students with disabilities.

\section{Definitions of Key Terms}

This section includes information regarding current laws concerning the inclusion of students with disabilities in the general education classroom, as well as, the meaning of accommodations and modifications. These definitions are deemed critical by the researcher to the understanding of the case study. Common knowledge of laws and such terms will ensure a common working knowledge which will be beneficial when providing instruction for students with disabilities.

\section{Laws}

Public Law 94-142 - this law was originally known as The Education for All Handicapped Children Act of 1975 and stated, "children with disabilities would have a right to education" and outlined that "State and local educational agencies would be held accountable for providing educational services for all handicapped children" (Wright \& Wright, 2016, p. 14).

IDEA 2004 - is an update to the initial IDEA which requires school districts to use research based interventions to help students with disabilities and provide early intervention (www.ed.gov; Wright \& Wright, 2016, p. 15).

Individuals with Disabilities Education Act (IDEA) - In addition to Section 504, the Individuals with Disabilities Education Act (IDEA) was established to ensure that students with disabilities receive "a free, appropriate, public education in the least 
restrictive environment" that meets their individualized needs (Aaron \& Loprest, 2012;

Shippen et al., 2005; Fuchs, 2010, p. 30; Dudley-Marling \& Burns, 2014, p. 14 \&16;

LeDoux, Graves, \& Burt, 2012, p. 20).

No Child Left Behind Act of 2001 - This act was created to provide improved education for all students to enhance academic achievement. The schools are now held more accountable for the education of all students. With this act came improvements in state assessments for students in grades K-12. Additional monies were made available to hire quality teachers. In addition, this act gave parents more choices if their student's district was failing (Karten, 2005; www.ed.gov; Wright \& Wright, 2016, p. 299-304).

Rehabilitation Act of 1973 - Beginning with the Rehabilitation Act of 1973, schools could no longer discriminate against students with disabilities (www.dese.mo.gov).

Section 504 - In particular, the civil rights law, Section 504, prohibited schools from receiving federal funds if discrimination against students with disabilities occurred (Aaron \& Loprest, 2012; Karten, 2005).

Every Student Succeeds Act (ESSA) - took the place of No Child Left Behind in 2015. The noteworthy updates include changes in the following areas: state assessment proficiency, college career and readiness, and school accountability for student success (Penuel, et. All, 2016, p. 2; Mathis \& Trujillo, 2016, 3-5; www.congressionaldigest.com, 2017, 4).

\section{Definitions}

Inclusion - Students with disabilities will take part in the same activities as their non-disabled peers. For this case study, inclusion is defined as learner diversity. This 
case study focuses on what students with disabilities need in order to show academic growth. For this research, the focus is partial inclusion of student with disabilities.

Least Restrictive Environment (LRE) - LRE ensures that students are not removed from the general education classroom without due cause. The law adopts the notion that all students with disabilities should receive instruction in the general education classroom to the "maximum extent appropriate" (Karten, 2005; Aron \& Loprest, 2012; Dudley-Marling \& Burns, 2014, p. 17). When students with disabilities cannot receive instructional services totally in the general education classroom, the IEP team will determine which educational setting is appropriate (Fuchs, 2010; SiegalHawley \& Frankenberg, 2012). It is important that all educational staff understand the law so students with disabilities receive the best, possible education.

Accommodations - "Accommodations are practices and procedures in the areas of administration, response, setting, and timing/scheduling that provide equitable instructional and assessment access for students with disabilities. Accommodations reduce or eliminate the effects of a student's disability and do not reduce learning expectations" (DESE.mo.gov) (see Appendix C for list of accommodations).

Modifications - are changes to the actual content on which the student is working. Students may only finish part of the assignment or test or the assignment or test given may be at a lower difficulty level than non-disabled peers (see Appendix $\mathrm{C}$ for list of modifications).

\section{Limitations, Assumptions, and Design Controls}

With this qualitative case study, as with many others, there are limitations and assumptions. While the case study is bound by one rural Missouri school, the content 
gathered will directly apply to the school district under study. It is possible this study could provide direction for surrounding school districts experiencing similar situations.

\section{Limitations}

This case study is focused solely on the operations of one, rural school district in Missouri. A limited number of teachers and administrators were available for collecting data. The researcher is currently employed with the school district. All participants will have an opportunity to review the information to avoid researcher bias.

\section{Assumptions}

This researcher assumes that general education teachers are not familiar with inclusion laws and practices. As stated in previous research, pre-service teachers are deficient in their training of teaching students with disabilities (VanSciver \& Conover, 2009; Fuchs, 2009-2010; Leatherman, 2007; Kosko \& Wilkins, 2009). Additional training is needed for general education teachers to feel successful with inclusion practices. There is a lack of communication between the general education teachers and the special education teachers (Fuchs, 2009-2010). There is little time provided for these teachers to collaborate on ways to ensure the success of inclusion of special education students (Shippen et al., 2005). Some of the general education teachers bring their own biases into the classroom and are unwilling to make inclusion work.

\section{Summary}

Laws mandate inclusion of special education students in the general education classroom. According to much of the research, general education teachers lack understanding of strategies to ensure the success of inclusion in the general education setting (LeDoux, Graves, Burt, 2012, p. 21; Taylor and Ringlaben, 2012, p. 16-17; Fuchs, 2009-2010, p. 30, 32-34). 
From much of the research, it is evident that teachers do not have ample opportunity to collaborate on ways to make inclusion of students with disabilities successful (Shippen, Crites, Houchins, Ramsey \& Simon, 2005, p.00; LeDoux, Graves, \& Burt, 2012, p. 24).

The general education teachers of students in grades 7-12 in the school district under study are struggling with successful inclusion of students with disabilities. There is a disconnect between the general education teachers and special education teachers in the school district. This qualitative case study will allow the researcher to collect information from the general education teachers and the special education teacher to understand their perspective of inclusion. One-to-one semi-structured interviews and classroom observations will allow the researcher to assemble data to overcome the current problem within the district. Once the data is collected, the researcher will use an inductive analysis approach to look for reoccurring themes and make generalizations based upon these themes. The information compiled will allow the researcher to formulate an action plan to resolve current problems with inclusion of special education students in the general education classrooms. 


\section{Review of Literature}

\section{Chapter II}

The battle for educational rights for children with disabilities continues today. Before the 1970s, students with disabilities were offered few programs for their education and these educational services were to be delivered at the expense of the parents (HicksMonroe, 2011, p. 61). However, through landmark cases and legislation, the education of students with disabilities has changed over the years. With the development of landmark cases such as Brown v. Board of Education, Pennsylvania Association for Retarded Children v. Commonwealth of Pennsylvania, and Mills v. Board of Education of District

of Columbia, students with disabilities can no longer be excluded or removed from public schools because of their disability.

Federal laws such as Elementary and Secondary Education Act of 1965, Section 504 of the Rehabilitation Act of 1973, Public Law 94-142: The Education for all Handicapped Children Act of 1975, No Child Left Behind 2001, Individuals with Disabilities Education Improvement Act of 2004, and Every Student Succeeds Act have forged a path for how students with disabilities should be educated.

\section{Conceptual Framework}

Student educational, emotional and safety needs must be met for learning to take place. This case study will utilize the Social Justice Theory regarding how to provide an environment in which all students can learn. Bell (as cited in Adams, Bell, Goodman, \& Joshi, 2016) describes Social Justice Theory as "both a process and a goal” (p. 1). "The goal of social justice is full and equitable participation of people from all social identity groups in a society that is mutually shaped to meet their needs" (Bell, as cited in Adams, 
Bell, Goodman, \& Joshi, 2016, p. 1). "The process for attaining the goal of social justice should also be democratic and participatory, respectful of human diversity and group differences, and inclusive and affirming of human agency and capacity for working collaboratively with others to create change" (Bell, as cited in Adams, Bell, Goodman, \& Joshi, 2016, p. 1).

\section{Social Justice Education}

Social justice in the classroom includes holding high expectations for all students, being respectful of differences, participating in self-reflection and being responsible for personal actions and thoughts (Picower, 2007, p. 6). Albritton, Huffman, and McClellan (2017) claim under the Social Justice Theory, schools should be educating the whole student, not solely focusing on their instruction but also their overall welfare (p. 20). Murray (2010) suggests social justice education should include open communication of school staff that provides refection of self-opinions, developing a school team that is dedicated to helping others understand the ideas surrounding "equity and social justice", and creating close relationships with the members of the school community (p. 48).

Bell (as cited in Adams, Bell, Goodman, \& Joshi, 2016) defines social justice education as the ability "to enable individuals to develop the critical analytical tools necessary to understand the structural features of oppression and their own socialization within oppressive systems (p. 4). Meister, Zimmer, \& Wright (2017) purpose four elements for classroom practices when teaching for social justice: "Challenge current ideology, student access to resources, honoring student talents and strengths and creating a supportive learning environment" (p. 93). Social Justice allows for all stakeholders to understand the inequities surrounding them. The only way to overcome inequity is to 
first acknowledge inequity exists and then be willing to become a change agent for those who are oppressed.

\section{Social Justice and Students with Disabilities}

Ostiguy, Peters, \& Shlasko (as cited in Adams, Bell, Goodman, \& Josh, 2016)

define Ableism as the "pervasive system that oppresses people with disabilities while privileging people who do not currently have disabilities" (p. 299). Wang (2017) adds "adequate instruction and less than a fair share of administrative and personal resources" are provided for students with disabilities (p. 5). In education, instructional practices and assessments are geared to the average learner. Inequalities in curriculum and needed resources create disadvantages in the school system. This system can make it difficult for students who learn differently.

Many students with disabilities come to school with needs that are different from that of the non-disabled student. For example, students with a reading disability may be reading one or two grade levels below that of their non-disabled peers. Other students may have behaviors that impede his or her learning. Student experiences can also play a role in student learning. Those students who live in poverty may not have the same exposure to experiences of students who do not live in poverty. Wang (2017) state "When students come from families that face stresses from poverty and struggle to afford adequate nutrition, they enter schools with problems that affect their readiness to learn" (p. 5). There are many ways in which students can be disadvantaged. Educators need to understand their students and community, so students are less marginalized.

Many students entering the school system are students with disabilities, such as Specific Learning Disabilities, Autism or Cognitive Impairment. Are they provided "full 
and equal participation" in their learning environment (DESE.mo.gov., 2018)? It is the responsibility of the school system to create an environment in which all students can learn.

\section{Social Justice Leadership}

Educational leaders have an opportunity to create an environment that is socially just. Albritton, Huffman \& McClellan (2017) state "School leaders who seek out marginalized students in schools to provide support and establish an environment of inclusiveness can be considered socially just" (p. 30). It is imperative school leaders create a school environment in which all students succeed. Pinto, Portelli, Rottmann, Pashby, Barrett, \& Mujuwamariya (2012) add "Equity and social justice must be prominent in all aspects of education policy... and conceived as a priority by educational leaders if we hope to make progress towards a truly democratic ideal" (p. 2).

Zhang, Goddard and Jakubiec (2018) concluded for school leaders to be effective they must be reactive (p. 77). Leaders need to be aware of inequalities and be prepared to improve these inequalities for the school community. DeMatthews and Mawhinney (2014) add social justice leaders act to overcome "policies and procedures" that continue to create discriminations (p. 846). Murray (2010) suggests developing an Equity Leadership Team to help monitor the inequalities in a school environment (p. 49).

\section{Review of Research}

\section{Landmark Case Law}

Brown v. Board of Education (1954). In Brown v. Board of Education (1954), children were segregation based on race. The Supreme Court found to separate children in a public-school setting would have harmful effect on the segregated students and in doing 
so would deny children the benefits of public education (Wright \& Wright, 2006, p. 12). Lawsuits from parents of children with disabilities against schools began after this decision. They claimed children with disabilities who are segregated were being discriminated against because of their disabilities (Wright \& Wright, 2006, p. 13). This case led to comprehensive changes in school policy and the way children with disabilities received educational instruction because the basis of this case was correspondingly related to children with disabilities who were deprived of an equivalent education as non-disabled students (Yell, Rogers \& Rogers, 1998, g. 220).

\section{Pennsylvania Association for Retarded Children v. Commonwealth of} Pennsylvania (PARC). In the 1970s, Pennsylvania Association for Retarded Children v. Commonwealth of Pennsylvania (PARC) children with mental retardation were excluded from public schools (Wright \& Wright, 2006, p. 13). Complainants charged "children with mental retardation were not receiving publicly supported education" (Yell, Rogers \& Rogers, 1998, p. 222). Yell, Rogers \& Rogers (1998) found four critical points:

First, "all children with mental retardation will benefit from education and training. Second, children with mental retardation must receive specialized instruction and not only provide the provision of academic experiences for children. Third, the state could not deny students with mental retardation access to free public education and training. Lastly, it was specified the earlier children with mental retardation were provided education, the greater amount of learning that could be predicted" (p. 222223).

This landmark case also concluded parental involvement must take place, as well as a dispute resolution (Wright \& Wright, 2006, p. 13). This ruling demonstrated students with 
disabilities should receive a public education and students with disabilities should be educated with programs similar to programs provided to non-disabled students (Yell, Rogers \& Rogers, 1998, p. 223).

Mills v. Board of Education of District of Columbia. In this 1970s landmark case; discipline of students with disabilities became a focus. Yell, Rogers and Rogers (1998) states when the District of Columbia school district suspended or expelled students with disabilities, they did not "provide all children with disabilities a publicly supported education" (p. 223). This case brought about due process safeguards and procedural safeguards. (Wright \& Wright, 2016, p. 13-14). According to Koeski (2017), students with disabilities who were not afforded a public education, violated due process (p. 802).

\section{Federal Laws}

Elementary and Secondary Education Act of 1965 (ESEA). This act was developed to provide "equality of education for underprivileged children" (Wright \& Wright, 2016, p. 13). In 1965, President Lyndon B. Johnson signed this act into law (Sharp, 2016, p. 9). This act was amended in 1966 to provide funding to school districts to be used to improve the education of students with disabilities (Wright \& Wright, 2016, p. 13). As stated by Martin, Martin, \& Terman (1996), ESEA provided "subsidized direct services" to be used for certain students in the public-school setting and is still the driving force for "federal support" in today's school settings (p. 27). According to Sharp (2016), ESEA was reauthorized on November 1, 1978, by President Carter (p. 10). In 1988, an amendment to ESEA held public schools accountable by requiring districts to show student growth and achievement with test scores (Sharp, 2016, p. 10). President George H. W. Bush met with governors to create national goals for academic success, and these goals were passed in 
1994 and termed Goals 2000: Educate America Act (Sharp, 2016, p.10). In October of 1994, President Bill Clinton reauthorizes ESEA to include the Improving America's Schools Act (IASA) (Sharp, 2016, p. 10). The next reauthorization came in January of 2002 when President George W. Bush renamed ESEA to the No Child Left Behind Act of 2001 (NCLB) (Sharp, 2016, p. 10). NCLB stood for 13 years when President Barack Obama signed the American Recovery and Reinvestment Act giving \$100 billion for education (Sharp, 2016, p. 10). In 2015, President Obama reauthorized ESEA, renaming it Every Student Succeeds Act (ESSA) (Sharp, 2016, p. 10; Wright \& Wright, 2016, p. 299).

Congressional Investigation (1972). PARC and Mills lead Congress to examine the education of students with disabilities (Wright \& Wright, 2016, p. 14). What Congress found was an estimated 8 million students with disabilities who required special education and related services, but only 3.9 million of these students were receiving the education they needed (Wright \& Wright, 2016. P. 14). Also 1.75 million students with disabilities were receiving no education services and 2.5 million where receiving unsuitable services (Wright \& Wright, 2016. P. 14). This investigation led to the development of laws to protect students with disabilities.

Section 504 of the Rehabilitation Act of 1973. The civil rights law of Section 504 took discrimination of students with disabilities one step further and prohibited schools from receiving federal funds if discrimination of students with disabilities occurred. The law helped to hold school systems accountable for the education of students with disabilities. This Act prohibits discrimination of "individuals with disabilities" for acts "relating to their disabilities (Wright \& Wright, 2016, p. 291-292). Under this law, students with disabilities are afforded the same access to opportunities as students without 
disabilities (Wright \& Wright, 2016, p. 291-292; Yell, Rogers \& Rogers, 1998, p. 223224).

\section{Public Law 94-142: The Education for All Handicapped Children Act of 1975.}

This law was passed to hold school districts accountable for the education of students with disabilities (Wright \& Wright, 2016, p. 14). Procedural safeguards were created to guard educational rights of students with disabilities (Wright \& Wright, 2016, p. 14). This law has now been amended and termed Individuals with Disabilities Education Improvement Act (IDEA) (Koeski, 2017, p. 802).

No Child Left Behind 2001. The No Child Left Behind Act of 2001 (NCLB) is a familiar law with many teachers in today's public education setting. This act was created to provide improved education for all students to enhance academic achievement. The schools are now held more accountable for the education of all students. With this act came improvements in state assessments for students in grades K-12. Additional monies were made available to hire quality teachers. Also, this act gave parents more choices if their student's district was failing (Karten, 2005; www.ed.gov). According to Wright and Wright (2016), "The purpose of this title is to ensure that all children have a fair, equal, and significant opportunity to obtain a high-quality education and reach, at minimum, proficiency on challenging State academic achievement standards and state academic assessments" (p. 299). This act was intended to provide opportunities to "close the gap" associated with test scores of students in public schools (Wright \& Wright, 2016, p. 300). Also, annual proficiency testing and research-based reading programs were developed under this act (Wright \& Wright, 2016, p. 300). Funding was provided to schools to launch reading programs based on reading research for students in kindergarten through third 
grade (Wright \& Wright, 2016, p. 301). The important goal was to improve reading abilities for students in kindergarten through third grade so that they would be reading at grade level or above at the end of third grade (Wright \& Wright, 2016, p. 301).

\section{Individuals with Disabilities Education Improvement Act of 2004 (IDEIA).}

The Individuals with Disabilities Education Act (IDEA) was established to ensure that students with disabilities receive "a free, appropriate, public education in the least restrictive environment" to meet individualized needs (Aaron \& Loprest, 2012; Shippen, Crites, Houchins, Ramsey \& Simon, 2005; Fuchs, 2009-2010; Aron \& Loprest, 2012; Koeski, 2017, p. 803). In addition, Wright and Wright (2016) state students with disabilities are to be provided services to "meet their unique needs, prepare them for life after high school and make sure their rights, as well as, their parents' rights are protected"' (p. 20).

There are many definitions outlined under IDEA. The first is a child with a disability. According to Wright and Wright (2016), a child who has a disability does not necessarily qualify for special education services. There must be an educational need. The student's disability must "adversely affect educational performance" to be qualified under $\operatorname{IDEA}($ p. 21).

Free Appropriate Public Education (FAPE) is also defined under IDEA. Students with disabilities receive instruction and other related services at the expense of the school district. This instruction and related services must "meet state standards, be appropriate and align with the students Individualized Education Program" (Wright \& Wright, 2016, p. 21). 
Highly qualified are requirements for special education teachers. Special education teachers who provide instruction for core subjects must meet the requirements for a highly qualified teacher. These requirements include:

i. "Full State certification as a special education teacher, or passed the State special education teacher licensing examination, and holds a license to teach in the State as a special education teacher" (Wright \& Wright, 2016, p. 51).

ii. "The teacher has not had special education certification or licensure requirements waived on an emergency, temporary, or provisional basis" (Wright \& Wright, 2016, p. 51).

iii. "The teacher holds at least a bachelor's degree" (Wright \& Wright, 2016, p. $52)$.

According to IDEA, special education is defined as "specially designed instruction, at no cost to the parents, to meet the unique needs of a child with a disability" (Wright \& Wright, 2016, p. 21). This instruction can include tutoring, rigorous academic remediation, help in the general education classroom, and behavior programs (Wright \& Wright, 2016, p. 21). This service may also include homebound instruction.

Transition services are provided under IDEA. These services facilitate successful transition from high school to employment or further education after graduation (Wright \& Wright, 2016, p. 22). Transition needs are based on student's interest and needs. Transition services consider students' strengths as well (Wright \& Wright, 2016, p. 22).

Along with IDEA, Least Restrictive Environment (LRE) became another acronym used in the special education world. Least Restrictive Environment (LRE) ensures that students are not removed from the regular classroom without due cause. Students with disabilities 
should be educated with non-disabled peers "to the maximum extent appropriate" (Wright \& Wright, 2016, p. 23). The law adopts the notion that all students with disabilities should receive instruction in the general education classroom (Karten, 2005; Aron \& Loprest, 2012). The LRE "refers to a continuum of placements, starting with full-time placement in general education setting, progressing to hospitals and separate institutions" (Koeski, 2017, p. 804). When students with disabilities can receive instruction in the general education classroom with their same-aged peers with aids and services, they should not be removed from the general education classroom setting. However, when students with disabilities cannot receive full instructional services in the general education classroom setting, the IEP team will determine which educational placement is appropriate (Fuchs, 2009-2010; Siegal-Hawley \& Frankenberg, 2012).

In order for a student to qualify for a disability, they must first be evaluated. This evaluation must be requested from a parent or an educational agency. Once the request is made, a notice will be given to the parent of the student. The evaluation must be conducted within 60 days of receiving a request to determine the "educational needs" of a student (Wright \& Wright, 2016, p. 93).

Once the evaluation process is complete, the educational agency will make a determination of eligibility based on the assessments completed. A copy of the evaluation and any other assessment information will be given to the parent. It is important to note the educational agency must determine a student with a disability is not based on lack of instruction, specifically lack of instruction in reading or math (Wright \& Wright, 2016, p. 96-97). If a student is found to be a student with a disability, an IEP will be developed. This IEP will be effective for a year at which time the educational agency and the parent 
will meet to discuss student progress. A re-evaluation will occur three years from the initial evaluation date (Wright \& Wright, 2016, p. 98-99).

According to Individualized Education Program (IEP), there are several types of placement available for students with disabilities. These placement options provide mainstreaming options for students with disabilities when full inclusion is not optimal for student learning. Placement options must be considered to meet the needs of a student with a disability. This placement decision must made by a group of people, which includes the parents, who are knowledgeable of the students' needs (Wright \& Wright, 2016, p. 208). LRE must be provided for the student with a disability and this placement must be as close as possible to the student's home (Wright \& Wright, 2016, p. 208). The following placement options are outlined on the IEP: (see Appendix A for a description of special education placements).

- Inside regular class at least $80 \%$ of time

- Inside regular class at least $40 \%$ to $79 \%$ of time

- Inside regular class less than $40 \%$ of time

- Public separate school (day) facility

- Private separate school (day) facility

- Public residential facility

- Private residential facility

- Home/Hospital

\section{Family Educational Rights and Privacy Act (FERPA).}

FERPA was enacted to guard the confidentiality of students and parents. Educational records are "those records, files, documents, and other materials which (i) 
contain information directly related to a student; and (ii) are maintained by an educational agency or institution or by a person acting for such agency or institution" (Wright \& Wright, 2016, p. 307). All educational records are available to parents and must be made available to parents upon request within forty-five days.

Confidentiality of student information is protected under FERPA. As stated by Wright \& Wright (2016) no identifiable information may be given out without parental consent. Identifiable information includes any information that would make student's identity traceable (p. 308).

FERPA also provides framework for the disclosure and destruction of student records. Parental consent is not needed for "other school officials" or "other schools in which the student has transferred to and intends to enroll" (Wright \& Wright, 2016, p. 308). Also, "law enforcement agencies and monitoring agencies" do not need consent for confidential records (Wright \& Wright, 2016, p. 308).

\section{Every Student Succeeds Act (ESSA).}

ESSA was introduced on December 10, 2015 by President Barack Obama to replace No Child Left Behind (Sharp, 2016, p. 9; Penuel, Meyer \& Valladares, 2016, p. 2). This act gave state and local agencies more control to:

1. Guarantee high college and career standards

2. States could direct resources to the schools who were in need of improvement

3. Use interventions from evidenced-based data to create an environment for learning

4. Use testing data to inform instruction

5. Improve preschool programs for children 
6. Find new strategies to increase student growth (Sharp, 2016, p. 2; Mathis \& Trujillo, 2016, p. 3).

ESSA not only ensures a fair and appropriate education for students with disabilities, it also holds school districts accountable for student achievement on state assessments. School districts must also establish high college and career standards for students for postsecondary success (Sharp, 2016, p. 9; Mathis \& Trujillo, 2016, p. 17).

Case and federal laws have dramatically changed the way in which students with disabilities are educated today. All students with disabilities are now provided a free and public education commensurate with that of non-disabled students. Students with disabilities are receiving instruction that is individualized and specific to their needs to facilitate academic success. However, there are barriers to inclusive education. According to Darrow (2009), these areas cause barriers to successful inclusion. Organizational barriers included the structure of schools and classrooms, how goals and instruction for disabled students are determined and classroom management (p. 29). With organizational barriers, lack of time to prepare for instruction of students with disabilities, lack of administrator support and problems with classroom management have been cited (Darrow, 2009, p. 29). Pivik, McComas, \& LaFlamme (2002) refers to environmental barriers as a problem with successful inclusion. Environmental barriers included physical access to the building and rooms in the building (p. 101). Darrow (2009) cites attitudinal barriers are a factor for successful inclusion (p. 30). Attitudinal barriers refer to the ideas, and perceptions teacher have toward provided instruction for students with disabilities (Darrow, 2009, p. 30; Dudley-Marling and Burns, 2014, p. 16). Pivik et al. (2002) adds to attitudinal barriers by defining intentional and unintentional attitudinal barriers. Knowledge barriers play a role 
to how successful inclusion is in the general education classroom. Knowledge barriers refer to the knowledge and skill of the teacher in providing accommodations and modification to the curriculum being taught in the general education classroom (Darrow, 2009, p. 30).

\section{Obstacles to inclusion.}

Dudley-Marling and Burns (2014) cite two different perspectives when discussing inclusion in the regular education classroom. One of these perspectives is termed Deficit Perspective (Dudley-Marling \& Burns, 2014, p. 18; Braunsteiner \& Mariano-Lapidus, 2014, p. 32). Dudley-Marling \& Burns (2014) share that Deficit Perspective presents itself when "ability" levels are different from the "norm" (p. 18). Students who tend to fall below the average are generally the focus of special education services and "deemed less than" (Dudley-Marling \& Burns, 2014, p. 18; Portelli \& Koneeny, 2018, p.139). Miller (1993) (as cited in Dudley-Marling \& Burns, 2014, p. 18) "the philosophy of deficiency takes the view that those whose performance deviates from the majority lack some critical attribute, ability, or potential" (p. 59). With the deficit perspective, students receive services to be able to live "normally in a normal environment" (Dudley-Marling \& Burns, 2014, p. 18). Dudley-Marling \& Burns (2014) claim the principal role of special education is to remediate and offer approaches for students to overcome their deficits and this process takes "specifically trained professionals" (p. 19). Portelli \& Koneeny (2018) claim this deficit "mentality" can cause a student to "internalize these deficits" (p. 139).

When applying inclusion under the view of deficit perspectives, school districts offer the "best instructional practices in the least restrictive environment" (Dudley-Marling \& Burns, 2014, p. 20). In this scenario, students "typically spend some time outside the regular education classroom" (Dudley-Marling \& Burns, 2014, p. 20). The Deficit 
perspective allows for student disabilities to be identified and "remediated" through the "evaluation and diagnosis process" (Dudley-Marling \& Burns, 2014, p. 21). This remediation is outlined in an "Individual Education Plan (IEP)" which is created by a support team which includes the parents (Dudley-Marling \& Burns, 2014, p. 21). On the other hand, as stated by Portelli \& Koneeny (2018) "deficit thinking negates inclusivity since those who subscribe to it are unlikely to strive for inclusion" (p. 139).

A second perspective identified by Dudley-Marling \& Burns (2014), is termed Social Constructivism Stance on Inclusion (p. 22). In this stance on inclusion, strengths and capabilities are the area of focus (Dudley-Marling \& Burns, 2014, p. 23). Social Constructivist "belief that all children, regardless of their differences, are smart, competent learners..." (Dudley-Marling \& Barns, 2014, p. 23). In Social Constructivist thinking, learners develop their knowledge through their experiences (Au, 1988, p. 299). Social Constructivists discard the idea of deficit thinking which is dominant in today's school systems (Dudley-Marling \& Burns, 2014, p. 23)

According to Dudley-Marling \& Burns (2014), another obstacle to full inclusion is "lack of specialized knowledge and training" (p. 20). General education teachers do not have the "necessary training" to "accommodate" students with disabilities in their classrooms and this information is "critical" for teachers to "...provide excellence in teaching students with special needs" (Dudley-Marling \& Burns, 2014, p. 20; DeSimone, Maldonado, \& Rodriguez, 2013, p. 4). Reyes, Hutchinson \& Little (2017) add "if the intent of federal and state legislation is to enhance learning for all students including students with disabilities, then it is imperative that educators receive the professional development that enable them to master the content and skills necessary to succeed in today's inclusive 
classroom" (p. 28). For full inclusion in the school system to be successful "...deploying skilled teachers..." is a necessity (Reyes et al., 2017, p. 34). Also, Reyes et al. (2017) adds employing teachers "with disabilities and diverse cultural and other backgrounds" will further the aid of full inclusion (p. 34). Hwang \& Evans (2011) found the attitudes of general education teachers were more positive than negative with regards to inclusion (II. 26). However, teacher willingness to "teach students with disabilities in their classroom" was more negative (Hwang \& Evans, 2011, I. 39).

Dudley-Marling \& Burns (2014) explain "large class sizes and inflexible curricula" also make it difficult to "accommodate" student disabilities in the general education classroom (p. 20). Dudley-Marling \& Burns (2014) state when teacher attentions are placed on accommodating students with disabilities, a "negative effect" will take place for non-disabled students in the regular education classroom (p. 20). Rose (2001), as cited in Braunsteiner \& Mariano-Lapidus (2014), states that teachers "felt that teaching students with disabilities involves additional time and resources that in turn restricts their ability to teach students without identified disabilities (p. 35).

\section{Teacher responsibility}

Schultz \& Simpson (2013) claim teachers need "realistic expectations" and must be able to adjust to the challenges presented in the classroom (p. 119). Teachers must understand their behavior and how this behavior affects student behavior (Schultz \& Simpson, 2012, p. 120-123). Since the passing of the Elementary and Secondary Education Act (ESEA), "highly qualified teacher" is a requirement (Strain, 2006, p.1). Highly qualified teachers affect all teachers and is a focus of teaching programs (Strain, 2006, p.

1). Teaching programs should prepare future teachers to identify and understand the 
environment in which they work (DeJarnette, n.d., p. 72). Before 2004, highly qualified teachers consisted of meeting requirements for a bachelor's degree, being certified and showing proof of subject matter (Strain, 2006, p. 3). In 2004, states were given some flexibility to determine what highly qualified meant (Strain, 2006, p. 3). As part of being highly qualified, teacher must demonstrate essential skills which include teaching and learning strategies (Strain, 2006, p. 5).

\section{Administrator responsibility}

Administrator support is a necessity if inclusion is successful in school districts (DeSimone, Maldonado, \& Rodriguez, 2013, p. 13). DeSimone et al. (2013) add teacher training and adequate resources are a requirement for successful inclusion (p. 13). According to Alquraini \& Gut (2012), administrators are key players needed to facilitate an "inclusive environment" (p. 52). One role administrators' can take to support an environment suited for inclusion is to provide collaboration time for teachers and other teams members to discuss concerns (Alquraini \& Gut, 2012, p. 52). Administrators should provide professional development opportunities for those teachers who may be struggling implementing instruction in an inclusive classroom.

\section{Summary}

Many landmark cases and laws have driven the development of the education of students with disabilities in the public-school systems. Many of the laws have been amended to accommodate the changed educational system, but the ideas surrounding inclusion and the education of students with disabilities continues to be debated. The laws enacted mandate students are provided "a free, appropriate, public education in the least 
restrictive environment." What this inclusive environment looks like continues to be unresolved.

Supporters of full inclusion state students with disabilities need to be educated in the general education classroom by the general education teacher. Supporters of the idea of mainstreaming students with disabilities state these students need to be educated in the "least restrictive environment" which depends on the individual needs of the student. Cases can be made for both of these ideas of inclusion. Both of these ideas have pros and cons for educating students with disabilities.

Teachers have a key responsibility when it comes to educating students with disabilities. Teachers must be aware of their limitations and shortcomings. Teachers must also be willing to reflect and improve in order for an inclusive environment to be successful. Schultz \& Simpson (2013) stated, "teacher attitudes toward the inclusion of students with disabilities is perhaps the single most important variable that influences teacher behavior" (p. 124).

Administrators must create an environment that is conducive to the successful inclusion of students with disabilities. Administrators must provide teachers with the necessary time to have quality collaboration with other team members. Administrators must also provide quality professional development that allows for teacher growth and development. This professional development will lead to a better understanding for teachers and improve their attitudes toward teaching students with disabilities.

The debate on how to educate students with disabilities will continue to progress. It is important educators and lawmakers keep in mind the needs of parents and students with disabilities when making important decisions regarding the education of students 
with disabilities. Input from all stakeholders will be the best remedy for the continual improvement of teaching students with disabilities. 


\section{Design for the Study \\ Chapter III}

A qualitative research study is a way of exploring and understanding problems within the natural occurrence (Creswell, 2009, p. 4; Hatch, 2002, p. 7). In this method, information is collected in the subjects setting and this information is analyzed to find emerging themes (Creswell, 2009, p. 4). The qualitative approach is narrative in design and uses open-ended questioning (Creswell, 2009, p. 16). The researcher collects thorough data using a diversity of collection methods (Creswell, 2009, p. 13).

In qualitative research, such as case studies, validity can be measured in several ways. Creswell (2009) reveals multiple strategies to be used to ensure the accuracy of the research (p. 191). Triangulation of data to establish themes, member checking to ensure accuracy of data collected, detailed descriptions, researcher bias, present evidence that opposes the general ideas of the theme, spend extended time in the research environment, peer debriefing and using an external auditor are among the ways to ensure validity (Creswell, 2009, p. 191-192).

This qualitative case study arose from current issues seen by this researcher within a rural Southeast Missouri school district. There seems to be a problem with the implementation of the accommodations and modifications outlined in student IEP's by the general education teachers in $7-12^{\text {th }}$ grade and their understanding as to why general education teachers must instruct students with disabilities. Teachers are unsure how to effectively implement these accommodations and modifications in the general education setting. Many teachers do not understand why they have to instruct students with disabilities in the general education classroom. 


\section{Research Questions}

RQ1: What are the perceptions of $7-12^{\text {th }}$ grade teachers regarding inclusion of students with special needs in the general education classroom setting?

RQ2: What do $7^{\text {th }}-12^{\text {th }}$ grade teachers perceive to be the obstacles to inclusion of students with special needs?

RQ3: How do $7^{\text {th }}-12^{\text {th }}$ grade teachers understand their responsibility for teaching all students?

RQ4: How do administrators perceive their role in facilitating teacher training and resources for mainstreaming and full inclusion of special needs services?

RQ5: How do administrators foster an environment that allows student with disabilities to be successful?

\section{Setting}

The participating school district is a small, rural district. Total enrollment from Pre-K to 12 is approximately 252 students. This enrollment yields approximately nine students per classroom and a student to teacher ratio of 8:1. The junior high consists of four core subject teachers and the high school consists of four core subject teachers. The high school administrator is also the building administrator for the junior high school.

\section{Participants and Sampling Procedures}

The participants in this case study are junior high and high school teachers who are currently teaching in inclusive classroom settings. Also, building administrators for the school district will be included in this case study. This case study will investigate the perspectives of junior high and high school teachers regarding inclusion in the general education setting. 
The researcher chose $7^{\text {th }}-12^{\text {th }}$ grade teachers and administrators because these grade levels have shown to have the most difficulty included student with disabilities in the general education classroom. These difficulties could stem from shorter class periods. Students in $7^{\text {th }}-12^{\text {th }}$ grade are with their general education classroom teachers for a 50minute period. This could make if difficult to teach all the content needed. Also, students begin receiving credits toward graduation in the $9^{\text {th }}$ grade. When including students with disabilities in the general education classroom, teachers may struggle modifying curriculum to satisfy graduation credits.

The elementary principal was included in this study. The elementary principal is part of the administrative district team. This team makes decision for the school district. The researcher feels her input would provide important information for this case study.

These participants have been purposefully selected for this case study. Purposeful selection is done to help the researcher gain information related to existing problems in the school district and to answer research questions (Creswell, 2009, p. 178). These participants were chosen because they have experience with teaching in inclusive classrooms. The experience of the participants in this case study range from two to nine years. The researcher will contact all participants in person and ask them to participate in this case study. Ten individuals will be asked to participate in one-to-one, semistructured interviews. These interviews will provide the researcher with diverse knowledge regarding how inclusion looks in the school district being studied. The information collected during this interview process will allow the researcher to make comparisons between teacher and administrator point of views. 
Observations will be conducted to gather data regarding the behaviors and activities of the participates (Creswell, 2009, p. 181). Four classroom observations will be conducted in core subject areas. The researcher will take a non-participant approach (Creswell, 2009, p. 181).

\section{Data Collection}

The purpose of this case study is to discover the general education teachers and administrators' perspectives regarding teaching students with disabilities in the general education classroom setting in grades 7-12. In order to examine this issue, this researcher will use a qualitative method to collect data. Creswell (2009) states, "this type of research is a means for exploring and understanding the meaning of individuals or groups ascribing to a social or human problem" (p. 232). Teacher interviews, administrator interviews and general education classroom observations will be utilized to gather data.

Data collection procedures. One-to-one teacher interviews will be conducted with the $7-12^{\text {th }}$-grade staff using a semi-structured format to inform the researcher the perspectivesof such teachers (Hatch, 2002). These interviews will be conducted using open-ended questioning providing opportunity for participants to elaborate if needed. The one-to-one, semi-structured interviewing format provides some structure to the interview process, but also allows the participant to speak freely about the topic (Hatch, 2002).

Teachers to be interviewed will vary in years of experience. The student population of these teachers will also vary in race and economic status. This data will help the researcher understand teacher perspectives and provide a starting place for administrators and the school district to increase the success of students with disabilities 
in the regular education classroom. At the approval of the participants, the interviews will be recorded using audio devices. After the interview, a formal transcription will be completed and analyzed. Once the transcription is completed and analyzed for themes, member checking will be used to determine the accuracy of the information (Creswell, 2009, p. 191).

Classroom observations will be conducted to observe students with disabilities in the general education setting. The researcher will be an observer in the classroom and will not participate in classroom activities. The researcher will collect field notes regarding instructional strategies used and the impact of such strategies. This type of observation will give the researcher "first-hand experience" (Creswell, 2009, p. 179).

Administrator interviews will be conducted so the researcher can get their perspective on the inclusion of students with disabilities in the classroom and how they, as administrators, aid in this process. The researcher will use the information collected from administrator interviews to analyze the data for determining common themes between administrator responses and teacher responses. The researcher will code all of the data to discover themes that emerge

The information gathered from the teacher interviews, classroom observations and administrator interviews will be analyzed using an inductive approach. Hatch (2002) states "Inductive data analysis is a search for patterns of meaning in data so that general statements about phenomena under investigation can be made" (p. 161). Each piece of data will be reviewed and then coded. This coding will be used to organize the information gathered into common themes (Creswell, 2009). These common themes will be used to inform an action plan. This action plan will be made available to the school 
district. The action plan can be a source of information used when making possible changes to enhance the instructional practices for students with disabilities in the general education classroom.

Before collection, the researcher will distribute an Informed Letter of Consent to ensure participants understand their rights concerning participation and confidentiality. Any participants uncomfortable will not be forced to participate. Participants will be informed as to which parties will receive the results of this case study. The researcher will assure confidentiality and protection for all parties involved.

Human subject's protection and other ethical considerations. All participants will remain confidential by using pseudonyms for individuals and roles. After data is analyzed, the information will be kept for five years in a locked filing cabinet. After this period, the collected data will be discarded. Participants will have access to research information after completed to account for accuracy within the study. The researcher will explain to the participants the idea of ownership of data (Creswell, 2002, p. 91).

All information acquired in connection with this case study will remain confidential. The information obtained with this research study will be coded using numbers so no identifiable information will be disclosed. The researcher will have sole access to the acquired information. All completed research will be kept in a locked filing cabinet. Subjects may remove themselves from this case study at any time without consequence.

\section{Data Analysis}

After all the data collected is transcribed and organized, the researcher will use an inductive approach for analysis. Hatch (2002) states inductive analysis' looks for themes or "patterns of meaning in data in order to make generalizations" (p. 161). The 
researcher will review the information and look for "frames of analysis" (Hatch, 2002, p. 162). All transcribed interviews and observation information will be coded using a process known as open coding (Creswell, 2009). When the data is analyzed and coded, the researcher will be able to determine underlying causes and implications from the data collected.

\section{Role of Researcher and Research Bias}

Researchers come into research studies with personal biases and beliefs. As a special education teacher working in the school district under study, I am no exception. Past experience in teaching students with special needs has shaped my view. Using Creswell's (2009) procedures to ensure validity will help prevent the potential of bias (p. 191). In addition, a proxy will be used to conduct the one-to-one, semi-structured interviews. A fellow researcher, who is current and familiar with interview protocol, will conduct the interviews. The interviews will be labeled as T1, T2, and so on to retain anonymity.

\section{Trustworthiness}

The aspect of trustworthiness is an important one. Understanding own biases as a researcher will provide a study that upholds the validity and reliability needed in order to be a trustworthy study. Researchers should use their knowledge of validity and reliability in order to produce a useful study.

Validity. Creswell (2009) defines validity as a "means for the researcher to check the accuracy of findings by using certain procedures" (p. 190). This study consists of interviews and observations which will provide data from various sources. After data is collected, the information will then be analyzed or triangulated for common themes and 
patterns. These themes and patterns will provide the researcher a way to show

consistency among the results. Member checking should be used to make certain the data collected conveys the ideas and thoughts of the participants. Once data is collected and triangulated, the researcher should allow the participants an opportunity to review the themes and patterns outlined.

Reliability. Creswell (2009) states "qualitative reliability is achieved when the results collected show consistency across different researchers and different projects" ( $\mathrm{p}$. 190). Results should be the same regardless of the research to show reliability. All data collected should be free from any mistakes during collection. Researchers should check over transcripts to prevent careless errors. Researchers need to clarify definitions of terms used. Checking often to make sure the correct definitions of terms are used throughout the analysis process will safeguard reliability.

\section{Limitations and Assumptions}

With this qualitative case study, as with many others, there are limitations and assumptions. While the generalization ability of this study is low, the content gathered will directly apply to the school district under study. It is possible this study could provide direction for surrounding school districts experiencing similar situations.

\section{Limitations}

This case study is focused solely on the operations of one, rural school district in Southeast Missouri. Other school districts were not studied in order to compare and contrast inclusion practices. Given the small size of the school district, there were a small number of teachers and administrators available for data collection. No first-year teachers are available for data collection. The researcher has not taught in the general 
education classroom setting and lacks diversity. The researcher is currently employed with the school district. The data collected would provide weak generalizations for other school districts.

\section{Assumptions}

It is the assumption of this researcher that general education teachers may not be familiar with classroom inclusion laws and practices. As stated in previous research, preservice teachers are deficient in their training of teaching students with disabilities (VanSciver \& Conover, 2009; Fuchs, 2009-2010; Leatherman, 2007; Kosko \& Wilkins, 2009). Additional training is needed for general education teachers to feel successful with inclusion practices.

There is a lack of communication between the general education teachers and the special education teachers (Fuchs, 2009-2010). There is little time provided for these teachers to collaborate on ways to ensure the success of inclusion of special education students (Shippen et al., 2005). Some of the general education teachers bring their own biases into the classroom and are unwilling to make inclusion work

\section{Summary}

The idea of inclusion within the school system is a major topic of discussion. Many laws mandate inclusion of special education students in the general education classroom. General education teachers are lacking in their understanding of ways to ensure the success of inclusion in the general education setting. Teachers are not provided ample opportunity to collaborate on ways to make inclusion of students with disabilities successful. 
The general education teachers of students in grades 7-12 in the school district under study are struggling with successful inclusion of students with disabilities. There is a disconnect between the general education teachers and special education teachers in the school district. This qualitative case study will allow the researcher to collect information from the general education teachers and the special education teacher to understand their perspective of inclusion. One-to-one semi-structured interviews and general education classroom observations will allow the researcher to assemble data to overcome the current problem within the district. Once the data is collected, the researcher will use an inductive analysis approach to look for reoccurring themes and make generalizations based upon these themes. The information compiled will allow the researcher to formulate an action plan to resolve current problems with inclusion of special education students in the general education classrooms. 


\section{Chapter IV: Research Findings \\ Introduction}

The inclusion of students with disabilities in the general education classroom is a current topic of discussion in the world of education. With reforms of Every Student Succeeds Act (ESSA), the way schools are held accountable for student success is changing. This change includes students with disabilities. School districts must provide a free, appropriate education to all students. It is important that teachers and school administrators are prepared for this change to the way students with disabilities are educated.

This chapter contains the results of the qualitative case study conducted to answer the following research questions:

RQ1: What are the perceptions of $7-12^{\text {th }}$ grade teachers regarding inclusion of students with special needs in the general education classroom setting?

RQ2: What do $7^{\text {th }}-12^{\text {th }}$ grade teacher perceive to be the obstacles to inclusion of students with special needs?

RQ3: How do $7^{\text {th }}-12^{\text {th }}$ grade teacher understand their responsibility for teaching all students?

RQ4: How do administrators perceive their role in facilitating teacher training and resources for partial inclusion of special needs services?

RQ5: How do administrators foster an environment that allows students with disabilities to be successful?

Information regarding the data collected for this qualitative research study and how the information ties back to the research questions are addressed. A qualitative 
research study is a narrative approach that uses open-ended questioning to gather data (Creswell, 2009, p. 16). A qualitative approach was chosen to analyze this case study. A qualitative method of research allows the researcher to collect data in the natural setting where the problem takes place (Creswell, 2009, p. 175). The researcher can talk directly with participants in a qualitative study and observe participants in the environment in which the problem is occurring. The information collected can then be analyzed for developing themes.

Data was collected from teachers and administrators using one-to-one interviews with the use of a proxy to avoid researcher bias. Also, observations in the general education classrooms were conducted in a non-participatory manner by the researcher. Once the data was collected, the researcher used an inductive approach for analysis to establish themes. Member checking was also used to ensure the accuracy of the data collected. Open coding was used to code the information gathered during the interviews and observations to look for reoccurring themes.

Nine participants were interviewed for this case study. Ten participants were asked, but one declined to participate. Four junior high general education teachers were interviewed for this case study which consists of $44 \%$ of the research sample. Three high school general education teachers were interviewed for this case study which comprises $33 \%$ of the research sample. Two administrators, one high school and one elementary school, were interviewed for this case study which comprises $22 \%$ of the research sample. The junior high staff were more willing to participant in this case study with $100 \%$ total participation. However, only $50 \%$ of the total high school population was represented in this case study. 
The years of teaching or administration experience among these participants range from 2-13. Three participants have 2-5 years of experience with the district which represents $33 \%$ of the research sample. Four participants have 6-10 years of experience with the district which represents $44 \%$ of the research sample. Two participants have 11 or more years of experience with the district which represents $22 \%$ of the research sample. Three of the participants had more than 11 years in education. They were at a different district or in a different position. Most of the participants in this case study are tenured faculty with the school district. These tenured faculty members have developed relationships with their colleagues. These relationships lend to better communication and support within the school district. This helps develop a better learning environment for students. Those teachers who are non-tenured faculty can bring another level of understanding to the issue of inclusion of students with disabilities in the general education classroom. They may have additional knowledge on how to successfully implement inclusion of students with disabilities in the general education classroom.

\section{Findings}

After collecting, organizing, and preparing the data for analysis, the researcher began the open coding process. The researcher read through the interview data again and made notes to the side. After reading the interviews, the researcher made a list of themes found from the research data that were aligned with what past literature states (Creswell, 2009, p. 186). The researcher read the interviews once more and used highlighting methods to note themes found. The researcher then noted participant comments aligned with each theme. These themes were then tied to the research questions to provide the researcher with data. 
The observation data collected was aligned with the interview data to provide additional insight into the teaching of the general education teachers in this case study. During the classroom observations, the researcher took a non-participatory approach. Individual teaching strategies were noted. The information collected during the observations was then analyzed to find connections with information provided through the one-on-one interviews. These observations were used to enhance the views expressed by the general education teachers during their interviews.

\section{Teacher perspectives around inclusion}

The responses to the teacher's perspectives regarding the inclusion of students with disabilities in the general education classroom were positive. When participants were asked to describe their thoughts about inclusion of students with disabilities in the general education classroom, they all had positive attitudes toward having students with disabilities in their classroom. Participant 5, who is a high school teacher with 2-5 years of experience, stated, "I believe that it's a wonderful idea." Participant 6 added, "I believe that it is a benefit to everyone involved for students with disabilities to be included in every other aspect of that community, so I feel that is always a good thing." Participant 2 said, "Regardless of a student's strengths or weakness, I feel they should have access to all the same resources and social interactions present in a general education classroom." Participant 1 felt "that it's a good idea to have them included in the classroom setting especially for socialization purposes." The previous literature investigated noted that general education classroom teachers demonstrated more negative attitudes when teacher students with disabilities in their classrooms. Previous literature found that many general education classroom teachers were not prepared on how to teach students with disabilities 
in the general education classroom. The participants in this case study demonstrated a positive attitude in regard to teaching students with disabilities in the general education classroom.

Social Justice Theory is the framework for this case study. Under the Social Justice Theory, all students are provided an equal learning environment. Administrators and teachers need to foster an environment that allows students with disabilities to be successful. The Social Justice Theory guides administrators and teachers on how to provide a school environment that is conducive to the learning of all students.

This theory was found in participant responses when asked their thoughts regarding inclusion of students with disabilities. In response to a follow-up question, Participant 5 stated, "It allows them to be seen as equal to others." Participant 7 added, "They are included in a group with the rest of the kids..." The observation data showed students with disabilities were included in group activities in the general education classroom. "I believe that student success is the priority for all of our staff and our administration," remarked Participant 2. Participant 1 stated, "They need to be treated on an equal playing field..." Social justice can be seen in the response of Participant 2 as well, "Students should not be restricted based on their ability level." In regard to a follow-up question, Participant 3 adds, "I think it just adds a diversity there (classroom)."

To gain insight into the teacher's understanding of their responsibility for teaching all students, the researcher asked participants to describe their role as a general education teacher with respect to teaching students with disabilities. Participant 3 answered, "I think my role is to give the best possible education I can to all of my kids, whether they have disabilities or not." Participant 6 added, "It's my responsibility to 
make sure they have access to the lessons that are being learned by their peers, and to make sure that any special support that they have is given, whatever resources I have to offer them, and make sure that all the bases are covered, as it were, in that situation." Participant 2 remarked on specific activities done in the classroom to support students with disabilities stating, "I create individualized lesson plans for students with disabilities that are in my classroom. This may include modified or adapted notes, or activities, or assignments. It might also include frequently checking for understanding or providing extended time to complete an assignment."

Previous literature revealed that Social Justice Theory focuses on teaching the whole student. Teaching the whole student refers to not only educational needs, but also emotional and safety needs as well. Social Justice Theory also refers to equal treatment of students (Murray, 2010, p. 48; Albritton, Huffman, \& McClellan, 2017, p. 30; Pinto et. al, 2012, p. 2). Participants in this case study revealed equality in education is important.

The researcher asked participants about their confidence level in teaching students with disabilities in the general education classroom to get a better understanding of teacher perceptions regarding inclusion. Participants revealed they were willing to teach students with disabilities in the general education classroom. More training would be helpful for inclusion of students with disabilities to be successful.

Participants 4 said, "Super confident. I feel I have a lot of patience with students and many resources to rely on to assist me in my classroom." Though several other participants, although confident, stated it depended on the type of disability. Participant 1 responded, “Those [disabilities] that I've had experience with on the job has been going well." Participant 7 stated, "It depends on the disability type I believe." "I think it kind of 
depends a little bit based on the kid," responded Participant 3. However, participants noted that more professional development would be beneficial to teaching students with disabilities in the general education classroom. Participant 5 remarked, "I'd love to have more tools to work with and I think that would just push me up a level of confidence." Participant 7 added, "So maybe just something with some of the more difficult science concepts. It would be nice to have some kind of skills to help them with that."

From the responses, participants are willing to teach students with disabilities in their classrooms. They would benefit from additional training on strategies to help students with disabilities in the general education classroom. Participants have access to student's Individual Education Plans (IEP), but they are not sure how to use this information to develop planning for students with disabilities. Also, participants seem to be more confident teaching students with disabilities they are more familiar with.

\section{Obstacles to Inclusion}

The researcher asked participants what they perceived to be the obstacles to inclusion. Participants noted training to be an obstacle. Six of the nine participants interviewed felt they were not adequately prepared to teach students with disabilities. This information is aligned with previous literature that shows a deficit in the amount of training preservice teachers are given (LeDoux, Graves, Burt, 2012, p. 21; Taylor and Ringlaben, 2012, p. 16-17; Fuchs, 2009-2010, p. 30, 32-34). Participant 1 states, "When it came to the college level, I don't feel that I was adequately prepared for it. I still am lacking in a lot of education for how to adequately prepare them." Participant 6 said, "With the exception of a few weeks within certain classes, I didn't receive very much in the way of specialized training. It was more focused on general education of your average 
student type situation." Participant 9 noted, "To be totally honest, going through the educational process of going through the program, it did not prepare me to lead or to teach students with disabilities.” Participant 5 explained, “...I feel that my biggest experience was not from my educational classes at college, but when I took a year and did an aide." In contrast, Participant 2 states, “Although my education background didn't emphasize teaching students with disabilities, I still feel like I'm somewhat well prepared." These participants were responding to their experiences with preservice training.

Participants in this case study are willing to teach students with disabilities in their classrooms, but they also feel more training would help them be successful in creating an environment in which all students can learn. It was good to see the participants were willing to teach students with disabilities in their classrooms. They demonstrated a positive attitude toward teaching students with disabilities, but the school district should provide professional development opportunities for teachers who feel they did not receive adequate training for teaching students with disabilities.

In addition, three of the nine participants received their education certification through alternative certification program. One of these participants teach at the junior high level and has 13 years of experience. Another participant with alternative certification teaches at the high school level and has seven years of experience. In addition, one participant with alternative certification teaches classes at the junior high and high school level and has 15 years of experience, but only two with the current school district under study. The alternative certification program allows educators who have a college degree to earn their certification by taking classes. However, the block 
classes, where students do their student teaching, are not required through the alternative certification program. Participant 2, who was an alternative certification participant, states "Considering I was not an education major, my background is somewhat limited." Participant 4 noted, "Because I had so little experience when I began, I had to rely on those with experience to guide me."

Lack of training on how to teach students with disabilities can be viewed as an obstacle. Whether participants take a traditional route to becoming a teacher or receive their education through an alternative certification path, participants in this study expressed a lack of adequate skills needed in order to teach students with disabilities in the general education classroom.

Participants interviewed expressed a need for professional development and training. When asked how professional development regarding teaching strategies for students with disabilities would benefit them, Participant 1 replied, "I think it would be great across the board." Several participants voiced a need for professional development with regards to strategies to be used in the general education classroom with students with disabilities. Participant 5, who received certification through the traditional route and has six years of classroom teaching experience, expressed a need for professional development in the area of scaffolding.

I always love to learn more, different ways to scaffold, or differentiation between how to reteach, and that sort of thing in the classroom. Sometimes I feel like there's times that I get set on a way to teach it, and I feel like that's the only way to teach it. But if I had these other options, a different technique, that I can step back and say, Oh, wait. Yeah, that would work. (Participant 5) 
Scaffolding refers to instructional techniques that increase student learning and allows the student to become more independent. Some examples of scaffolding in the classroom could include activating prior knowledge. Activating prior knowledge allows students to have a reference for the learning activities. During observations, teachers used student's prior knowledge to enhance student understanding of content. Scaffolding can include think-pair-share where students talk with their peers to develop a better understanding of the topic in discussion. During an observation, students were working with peers to complete a diagram of a life cycle. Pre-teaching vocabulary can be considered scaffolding student learning. During a general education classroom observation, students were learning vocabulary before their lesson. Using visual aids in the classroom will also help to increase student learning. Visual aids such as graphic organizers, KWL charts, maps, and smartboards were used (see Appendix B for an explanation of resources for extra support). In addition, Chrome Books were used to increase student engagement in learning. Although scaffolding ideas can be beneficial for students with disabilities, these ideas can be an obstacle if teachers have not been trained on how to implement these strategies in the classroom.

Participants were open and willing to learn new and different techniques to provide a better learning environment for students with disabilities. As stated by Participant 5, "I'm open to learning because the strategies that I learn in professional development many not just be helpful to one student. It may be helpful to all students." Participants 1 and 3 agree that professional development techniques learned can help all students, not just students with disabilities. Participant 2 describes "From what I would learn, I would modify my instruction accordingly to maximize the success of students." 
An additional obstacle noted by participants was time. Time referring to instructional time, the amount of time it takes to prepare for teaching students with disabilities and the amount of time it takes students with disabilities to learn the content being taught. Participant 1 expressed, "The main obstacles that I do find is time. I try to make the best use of my time as well for them, but I feel that sometimes they need more of my attention and that, at times, might pull away from someone else who needs it as well." Participant 2 said, "Working one-on-one with students with disabilities is extremely important. However, finding the opportunity to do so with a classroom full of other students can sometimes be a struggle." Participant 7 added, "Sometimes they require more time, and you can't quite get to everything you need to cover with them during the class period. So, I feel like I'm running short on time trying to get them what they need and then keep the other kids on track too." The amount of time it takes educators to prepare and teach students with disabilities has been noted in previous literature. Previous research shows some teachers feel they do not have enough time to prepare and teach students with disabilities in the general education classroom.

General education teachers of grades $7^{\text {th }}-12^{\text {th }}$ perceive training and time as obstacles to inclusion. General education teachers, who received their certification through the alternative certification route, felt they did not have any training as a preservice teacher that prepared them for teaching students with disabilities. Those teachers who completed an education program for preservice teachers feel they would benefit from training on specific strategies to use in the classroom. Teacher's noted an additional obstacle to teaching students with disabilities in the classroom was time. Planning for students with disabilities takes more time and it takes students with 
disabilities longer to learn concepts. Finding time to make sure every student gets the right amount of support can be difficult.

\section{Teaching All Students}

During the interview process, participants referenced the importance of communication and collaboration with their colleges and administrators. Participant 7 answered, "I go talk to the special ed teacher that has had that student possibly, and just find out what the strengths and weaknesses are." "I just try to be in communication with the special ed teacher to make sure that she knows what we're doing in the regular classroom so that when they come to her for resource, she can better help them." Participant 1 emphasized, “...Work as a teammate with not only the parents, the spec ed teacher, and the student to work for success of that student." Participant 4 added, "I also participate in IEP meetings with the special education department, as well as the parents, offering any information I feel would be beneficial in my student's education."

Participants were asked how they foster an environment that allows for diversity within the classroom. The researcher wanted to seek understanding regarding the learning environment for students with disabilities and how teachers see their responsibility in providing this learning environment. The data indicated most participants provide a safe and supportive learning environment for students with disabilities. Participant 5 answered, "I also like to give the idea that whenever you're in my room, it's a safe room." Participant 1 replied, "I feel that it's a big role to make certain that they are included." In addition, Participant 4 stated, "I'm constantly encouraging all of them to offer their personal insights to our lessons and allow them to draw from their personal experiences to make those connections." Participant 3 said, "I try to make it so that 
everybody is comfortable with their differences." Participant 2 added, "I try to create a judgement free zone in my classroom." Furthermore, Participant 6 replied, "I welcome open discussion, and I try to encourage the understanding of others' differing opinions." Observation data confirmed students with disabilities felt safe to respond. During all four observations, students with disabilities were noted as providing responses to questions presented orally to the whole class.

The researcher wanted to gain insight on how supported participants felt in their role for teaching students with disabilities in the general education classroom. Participants were asked to describe the level of support they have received from other colleagues and administrators. Responses indicated that participants felt supported by their colleges and administrators. Participant 5 stated, "They're always checking in on you." Participant 6 answered, "I feel comfortable approaching my colleagues with issues that they may have more experience with and so forth." Participant 2 replied, "Anytime I have any questions or concerns, they're promptly answered and dealt with." Participant 3 added, "I think that, especially in my hallway, we're a team..., and I think that we work well together as far as supporting each other. I think, overall, our school has a pretty supportive atmosphere." Participant 4 commented on the special education director and principal "do a great job of supporting me," however, there is limited contact with the special education teacher and "It appears I only see this individual when things appear to look bad on their end, and sometimes I feel like there's a shift of blame."

The participants in this case study showed they feel supported by their colleagues and administration. This is a contrast to previous literature that showed teachers blame lack of administrator support as a problem with the success of inclusion of students with 
disabilities (Darrow, 2009, p. 29). Environmental and attitudinal barriers were noted in previous literature as barriers to successful inclusion (Darrow, 2009, p. 30; DudleyMarling and Burns, 2014, p. 16; Pivik et al., 2002, p. 101). The participants in this case study challenged this notion. The participants in this case study are willing to teach students with disabilities in the general education classroom and feel supported by colleagues and administration.

\section{Administrator Role}

This case study interviewed two building administrators. One administrator is for the junior high and high school buildings and the other administrator is over the elementary building. I added the elementary building administrator because this administrator collaborates with the junior high and high school administrator during monthly administration meetings in which curriculum ideas are discussed. The junior high and high school administrator has been in the field of education for 25 years. This administrator has been with the district under study for five years. All five years have been served as an administrator. The elementary principal has been in education for 18 years. This administrator has been with the district under study for 18 years, nine years as a classroom teacher and nine years as an administrator.

The researcher asked building administrators to describe their role in facilitating inclusion, at any level, in the district to expand knowledge of how administrators perceive their role in inclusion of students with disabilities in the general education classroom. When asked to describe their role in facilitating inclusion of students with disabilities in the general education classroom, Participant 9 stated that "It's my job to help teachers find the resources that they need, whether it be financial or maybe ideas of 
what works best, like a best practice, through networking." Participant 8 added, "I would say I have an auxiliary role in that, in our district, just because our special education director works directly with the teachers and takes care of all of that."

After interviewing both administrators, they viewed their roles in creating an environment that supports inclusion of students with disabilities differently. Participant 9 seemed to take more of a hands-on approach and actively helping teachers by providing the supports they need to create an environment conducive to inclusion. Whereas, participant 8 was less hands on and only provided support when there was a need. Participant 8 allowed the general education classroom teachers to determine how much support was needed.

Participants were asked to describe their role in facilitating professional development opportunities for teachers who struggle teaching students with disabilities. Participant 8 replied, "If and when that concern is brought to me, my role would be that I go out and explore and try to find opportunities, maybe even some literature, provide examples. Whatever it is that the teacher needs, I try to be that support.” Participant 9 added, "We [administrator and classroom teacher] sit down, we talk about strategies, different strategies. Not only that, you've got to encourage the teacher that you're there to support them because if they're not confident doing it, then it's not going to happen anyway."

When asked to describe how professional development shows in the classroom, Participant 8 stated, "Well, currently, our professional development is...it's around John Hattie's work with visible learning, and so stepping into any of our classrooms, you would be able to see some of that in place." Participant 9 added, "I know it's there and 
working when I go in and I see that the student is engaged, whether it's students with disabilities or regular ed students." "Everyone must be included."

Administrators were asked what support role do they provide to staff when implementing inclusion of students with disabilities. The researcher wanted more insight on how administrators view their roles. Participant 8 responded, “...I'm in a unique position in our district just because I have my flexibility of where I can be and where I have to be. And so a lot of times I serve as the aid, if you will, in the classroom to help facilitate that and providing resources, being a resource." Participant 8 serves an administrator role and has more freedom to move from classroom to classroom to help when needed.

The researcher wanted to understand the perspective of the administrator's knowledge regarding concerns with inclusion of students with disabilities. Administrators were asked to describe obstacles to teaching students with disabilities. Participant 9 remarked,

"Resources, of course, financial resources. Maybe physical resources, having book or anything that we need. And we have young teachers here who probably didn't go through the education program to learn how to deal with inclusion as well. Lack of professional development in our area, when it comes to dealing with inclusion."

Participant 8 added, "Manpower has definitely been an obstacle for us, and not because we don't have enough teachers. We don't have enough teachers at the right time, and so we have to be creative with how we use our staff." 
The researcher asked administrators to describe their thoughts about inclusion in order to expand their knowledge on how administrators foster an environment that allows students with disabilities to be successful. Participant 9 answered, "My thought is the more we can get them in regular ed classes, the better. I am a proponent of socialization, and I think socializing students helps them academically." Participant 8 replied, "We are looking to close that gap, and I am fully supporting including our students with disabilities."

Participants were asked to provide their thoughts on why inclusion is important to give the researcher an understanding of administrations attitude of inclusions. Previous literature states the attitude of those implementing inclusion of students with disabilities in the general education classroom with be a factor in determining the success of such ideas (Darrow, 2009, p. 30; Dudley-Marling and Burns, 2014, p. 16; Pivik et al., 2002, p. 105). Participant 8 answered,

"We have seen time and time again in our district that in our sub-group achievement, whether it is our state testing, whether it is our progress monitoring or our benchmark testing, that our special ed students are the ones who are not making as much progress as their peers. If they were in competition with themselves, they show improvement, but with regular education peers, they are not. And so we are, as a district, thinking that our next step is fully including the students that we have into the classroom."

The information provided by the administrators in this case study offers insight into how they foster an environment that allows special education students to be successful. One way to foster an environment for success is to feel inclusion is important. 
Furthermore, having a positive attitude toward the idea of inclusion will build a successful learning environment for all students. Understanding that all students should have equal access to resources and access to the best education is vital.

Participants were asked what they expect to see from teachers in an inclusive classroom in order to help the researcher understand what their ideas for an environment that supports students with disabilities in the classroom would look like. Participant 8 stated, "I expect to see collaboration with the special ed teachers. And I expect a welcoming and accepting attitude towards this change in instruction.” Participant 9 answered, "Everyone must be included."

\section{Conclusion}

This chapter contains the results of a quantitative study to reveal the perspectives of teacher's and administrator's regarding inclusion of students with disabilities in the general education classroom. Nine participants were interviewed, and the interview questions were open-ended in nature. The participants were both male and female and experienced ranged from two years to more than eleven years of experience.

The participant interviews revealed several key aspects to inclusion of students with disabilities in the general education classroom. Positive attitudes toward teaching students with disabilities are needed for inclusion to be successful. The teachers and administrators in this case study showed positive attitudes toward inclusion. Teachers and administrators felt students with disabilities can be instructed in the general education classroom. Teachers stated they were confident in teaching students with disabilities, however, they felt more professional development and training would aid in the success of teaching students with disabilities. 
Participants agreed that all students should have equal access to education. Being able to include students with disabilities in the general education classroom would benefit all learners and increase learning. Providing the same resources to curriculum and other educational aspects is imperative for students with disabilities.

Teachers and administrators in this case study were willing to accept responsibilities associated with teaching students with disabilities. One of these responsibilities includes communicating with other colleagues and administrators regarding students with disabilities. Teachers and administrators assume responsibilities for making special lessons, providing special supports as needed and making sure students with disabilities have access to the same resources as their non-disabled peers.

Teachers and administrators felt diversity in the classroom is important for all students. Participants' responses showed they provide a safe and supportive environment for students with disabilities. Participants expressed the importance of making students feel included.

Teacher responses showed they felt supported by colleagues and administration. Participants expressed satisfaction with how support was provided in this school district. Participants were able to find help with concerns they may experience in the general education classroom.

The school district under study has a good foundation in place for the success of inclusion of students with disabilities. The greatest need expressed by participants is a need for professional development to help with instructional strategies needed to provide the best learning environment for students with disabilities. The positive attitudes of 
teachers and administrators in this district will help in providing a learning environment in which students with disabilities can be successful. 


\section{Chapter V: Conclusion, Discussion, And Suggestions For Future Research}

Laws governing education are directing school districts towards inclusion of students with disabilities in the general education classroom. IDEA and ESSA are laws that are forcing school districts to provide learning for students with disabilities in the general education classroom setting. With this latest push in the education world, school districts must prepare for this change.

The purpose of this case study is to gain insight into the general educator and building administrators' perspectives on teaching students with disabilities in the general education classroom setting. This study also examines current policies and laws regarding inclusion that guide education at this time.

The research questions that guide this study are as follows:

RQ1: What are the perceptions of $7-12^{\text {th }}$ grade teachers regarding inclusion of students with special needs in the general education classroom setting?

RQ2: What do $7^{\text {th }}-12^{\text {th }}$ grade teachers perceive to be the obstacles to inclusion of students with special needs?

RQ3: How do $7^{\text {th }}-12^{\text {th }}$ grade teachers understand their responsibility for teaching all students?

RQ4: How do administrators perceive their role in facilitating teacher training and resources for partial inclusion and full inclusion of special needs services?

RQ5: How do administrators foster an environment that allows students with disabilities to be successful? 
An interview protocol was developed, using the research questions above. The inquiry focused on teacher perspective data gathered with protocol items and through classroom observations.

Social Justice Theory is the conceptual framework that informs this research. The Social Justice Theory provides a lens of equality for all students to learn. This theory holds all students to high expectations for learning and individual responsibility for this learning (Picower, 2007, p. 6). Social Justice Theory describes schools should be educating the whole student (Albritton, Huffman, and McClellan, 2017, p. 20). Understanding the needs of all stakeholders will help in providing a learning environment in which all students are successful. Communication with school staff, leadership teams and developing relationships will form a school environment where social justice can be visible (Murray, 2010, p. 48). Understanding teacher and administrator perspectives are key in developing an environment in which all students can learn.

Students with disabilities do not have fair access to acceptable instruction or resources (Wang, 2017, p. 5). The theory of social justice helps to overcome disadvantages presented in the school system. When stakeholders view the school system through the social justice lens, equality is the focus. Understanding one's own views and being willing to be reactive to injustices within the school environment will create a learning environment in which all students will benefit.

\section{Discussion}

This qualitative case study explores the perspectives of teachers in a rural, Missouri school regarding inclusion of students with disabilities in the general education classroom in grades $7^{\text {th }}-12^{\text {th }}$. Concerns on how to include students with disabilities in the 
general education classroom among teacher's in grades $7^{\text {th }}-12^{\text {th }}$ in the rural district under study have been raised. A case study allows a researcher to study a problem in the natural occurrence (Creswell, 2009, p. 4). The teacher's perspectives from this study examined the underlying problems of inclusion of students with disabilities in the general education classroom. This case study employed the use of semi-structured interviews using openended questioning. Nine participants were interviewed. Ten participants were asked to participate, however, one teacher chose not to take part in the interviews. The interviewees consisted of seven general education classroom teachers and two administrators. The interviews were transcribed and member checking was used to increase the accuracy of the interview information collected. In addition, the researcher conducted classroom observations of four participating teachers. The researcher utilized a non-participant role during the classroom observations to gather information.

Inclusion is described as "full time placement" of students with disabilities in the general education classroom (Buli-Holmberg \& Jeyaprathaban, 2016, p. 119). The latest legislative act, Every Student Succeeds Act (ESSA), ensures the academic success of all students and these students will be required to meet state assessment proficiency, be prepared for post-secondary activities and schools will be held accountable for student success (Penuel, et. All, 2016, p. 2; Mathis \& Trujillo, 2016, 3-5; www.congressionaldigest.com, 2017, 4; Karten, 2005; www.ed.gov; Wright \& Wright, 2016, p. 299-304). Previous literature states students with disabilities do not have access to adequate curriculum or resources (Wang, 2017, p. 5). One way for students with disabilities to gain access to curriculum and resources is to be included in the general 
education classroom for instruction. This will aid in meeting state assessment proficiency and better prepare students for post-secondary success.

Inclusion of students with disabilities in the general education classroom has advantages. Students with learning disabilities who receive instruction in the general education classroom will have access to the same instruction as non-disabled peers. When students receive instruction in the general education classroom, they will also have access to the same resources available to their non-disabled peers. These opportunities create an equal learning environment for all students. Many of the teachers interviewed believed that when students with disabilities received instruction in the general education classroom, they had access to the same resources as students without disabilities. For instance, participant 2 commented, "I feel they [students with disabilities] should have access to all the same resources and social interactions present in the general education classroom." Participant 4 added,

"While it can be challenging at times, the overall experience they [students with disabilities] had is beneficial in many ways such as giving them the opportunity to participate in class discussions, work in peer groups, and enjoy classroom activities they might miss out on if they were in another classroom."

Inclusion of students with disabilities does present disadvantages for general education teachers. Teaching students with disabilities in the general education classroom requires more time. One participant stated, "Working one-on-one with students with disabilities is extremely important, however, finding the opportunity to do so with a classroom full of other students can sometimes be a struggle." Another participant added, "Sometimes they [students with disabilities] require more time, and you can't quite get to 
everything you need to cover with them during the class period...there's just not enough time to get them everything they need." None of the teachers interviewed in this case study spoke to how they managed their time. It would be interesting to gather additional information from the teachers on ways they manage their time.

Rural schools may be more open to inclusion of students with disabilities because they are usually smaller in size as compared to urban school districts. The school district under study houses K-12 grade students in the same location. Teachers in this district have the unique ability to watch students develop through their school career. In the opinion of this researcher, this can provide an opportunity to begin building relationships in elementary school. When students enter junior high, teacher-student relationships can be underway.

Seven themes were found from the non-structured interviews. These themes include professional development and teacher training, a safe and supportive environment, teacher and administrator responsibilities, equality, communication and collaboration, positive attitudes, and obstacles to inclusion. These themes provide insight to the inclusion policy in place today.

\section{Professional Development/Teacher Training}

Findings from this case study show that general education teacher's and building administrators feel a need for more professional development for teaching students with disabilities. Teachers and administrators feel training on specific teaching strategies, such as scaffolding or differentiated instruction, would be beneficial for teaching students with disabilities in the general education classroom setting. 
Teacher's mentioned professional development on scaffolding instruction or differentiated instruction would be helpful. Scaffolding techniques that can be used in the classroom include activating prior knowledge on content at the beginning of a lesson. This will allow students to review what they already know about the content being taught. Pre-teaching vocabulary is another idea associated with scaffolding instruction. Students must understand the vocabulary and terms being used to teach content ideas. Peer grouping gives students time to discuss concepts which will enhance their understanding too. In addition, graphic organizers, pictures and charts are good visual aids that can be used in the general education classroom to increase learning (see Appendix B for types of resources for extra support).

Administrators stated any professional development that would help students is important. The administrator's role would be to provide learning opportunities for teachers and staff to increase their understanding of helpful strategies that can be used to teach students with disabilities in the general education classroom. All general education teachers and administrators interviewed felt that professional development for teaching students with disabilities would be useful. One participant stated, "Well, I think any training regarding teaching strategies is beneficial in all areas." Another participant added, "I always love to learn more, different ways to scaffold, or differentiate between how to reteach, and that sort of thing in the classroom." These teacher perspectives align with previous literature. Dudley-Marling \& Burns (2014) noted that a "lack of specialized knowledge and training" is an obstacle to full inclusion of students with disabilities (p. 20). Further, Dudley-Marling \& Burns (2014) and DeSimone, Maldonado, \& Rodriquez (2013) expressed it is important for teachers to have training needed to provide the best 
education for students with disabilities (p. 20 \& p. 4). Reyes, Hutchinson \& Little (2017) add for teachers to improve the learning of students with disabilities, then it is important that teacher's receive professional development that provide them the skills need to teach students with disabilities (p. 28).

The researcher agrees with the information gathered regarding professional development and training. In the experience of the researcher, many general education teachers would benefit from professional development and training on teaching students with disabilities. Teacher's would benefit on how to utilize ideas of scaffolding for all learners. Training on using peer grouping, graphic organizers, pictures and charts would be helpful. It is also the opinion of the researcher, general education teachers need more explanation regarding accommodations and modifications outline in student Individual Education Plans. More training would increase teacher understanding of how to increase the learning of students with disabilities in the general education classroom.

\section{Safe/Supportive Environment}

The research revealed that teachers and administrators want to provide a safe and supportive environment for students with disabilities. General education teachers want students with disabilities to feel included when they are in the general education classroom. General education teachers want students to know that their classrooms are judgement-free zones and it's ok to make mistakes. Teacher interviews also revealed, they want students to be comfortable with their differences. One participant expressed that she tells students, "Even if you think you've got the answer wrong, still tell me." Another participant responded, "I'm constantly encouraging all of them to offer their personal insights to our lessons and allow them to draw from their personal experiences 
to make those connections." One of the teacher's interviewed added, "I welcome open discussion, and I try to encourage the understanding of others' differing opinions." Administrator interviews discovered they support all students in the general education classroom. Administration want students with disabilities to feel a sense of community and family. Principals are willing to aid in the classroom and provide resources when needed. One participant stated, "My role would be that I go out and explore and try to find opportunities [for training], maybe even some literature or provide examples." Another participant further explained, "What I try to do is I try to bring in teachers that I know are doing a good job when it comes to inclusion and use their expertise with the teachers..." Previous literature shows that successful inclusion will depend on the way leadership is conceived (Ryan, 2006, p. 7). Darrow (2009) states "lack of administrator support" has been cited as a barrier to successful inclusion. From the teacher and administrator interview information, administrator support is not lacking in this district.

\section{Teacher/Administrator Responsibility}

An additional theme which developed from the interviews is teacher and administrator responsibility toward ensuring successful inclusion of students with disabilities in the general education classroom. General education teachers felt it was their responsibility to promote academic growth for all students. They believed that making sure students with disabilities, as well as non-disabled students, require access to lesson and special supports. Teachers should be aware of student's Individualized Educations Plans (IEP) and provide instruction with accommodations and modifications. In addition, interviews found teachers felt they should be prepared, but flexible. A 
participant explained, "It's my responsibility to make sure they [students with disabilities] have access to the lessons that are being learned by their peers, and to make sure that any special support that they have is given..." Another participant commented, "I've inquired about strategies and tips to help out a few of my students who have issues with reading. She's [Special Education Director] been more than willing to help out in that area and has actually given me some strategies that I have implemented.” Also, general education teachers can take some time to observe other general education teachers to observe teaching strategies used.

Administrator interviews revealed their responsibility was to help teachers find resources they need to help students with disabilities be successful in the general education classroom. The interviews revealed when general education teachers need resources to help with instruction of students with disabilities, they go to their colleagues. Teachers use the knowledge of their colleagues to help with strategies to use when teaching students with disabilities. As one administrator explained, "I try to bring in teacher's that I know are doing a good job when it comes to inclusion." Another administrator sees their responsibility as a collaboration with the special education director. Listening to ideas and helping in deciding how these ideas will work within the district.

Administrators need to provide professional development for visible learning such as the use of graphic organizers, smartboards, charts and pictures (see Appendix B for types of resources for extra support). Peer coaching or peer budding can also be used in the general education classroom to help students with disabilities. Peer coaching or the use of a peer buddy can be used during group work. Teachers can pair students working 
at grade level with students who are working below grade level. Scaffolding instruction can also be used in an inclusive general education classroom. General education teachers can use hands on activities when possible to further develop student engagement.

Technology in the classroom can be a valuable resource when teaching students with disabilities. Technology such as Chrome Books or Smartboards are good resources to use to increase student engagement. Another responsibility for administrators is to make sure students are engaged and they are receiving all the instruction as non-disabled peers.

After reviewing the data collected, I feel the teacher and administrators in our school district do a good job of promoting academic growth for students with disabilities. Teachers are good at implementing accommodations and modifications outlined in student IEP's and make sure students with disabilities are provided the highest education opportunities. Our district sets expectations for all students and provide supports for success in meeting those expectations.

\section{Equality}

Teachers interviewed felt students with disabilities should not be restricted based on their ability level alone. Teachers felt students with disabilities should have the opportunity to interact with non-disabled peers and this interaction would benefit all students. By including students with disabilities in the general education classroom, a better classroom community would develop. A community that consisted of diversity would benefit all students.

Administrators revealed through interviews everyone must be included and the administration fully supported the inclusion of students with disabilities in the general education classroom. Administrators felt students with disabilities are part of our 
community and deserve a free, public education without restraints. This is one way administrators foster an environment that allows students with disabilities to be successful.

The data collected aligns with the conceptual framework outlined in the previous chapter. According to Bursa \& Ersoy (2016), social justice includes ideas such as equality, tolerance, respect, and fairness (p. 326). In order for a social justice environment to exist, participants must understand their own feelings (Murray, 2010, p. 48). When interviewing the teachers and administrators, I felt that everyone was in support of including students with disabilities in the general education classroom. Ryan (2006) adds only when students who are disadvantaged are included in a meaningful way, will social justice to be attained (p. 6). All information gathered aligns with this thinking.

\section{Communication/Collaboration}

The data collected revealed teachers and administrators felt communication and collaboration were key components to the success of inclusion of students with disabilities in the general education classroom. Teachers felt maintaining open communication with the special education department was important. Accessibility allows questions regarding students who have IEP's to be answered in a timely manner. One participant commented, "They [special education teachers] always check in on you through emails." "They stop by the classroom to see how things are going."

Many teachers felt the school district under study has a very supportive atmosphere. A participant commented they felt they had complete support from colleagues and administrators. Another participant added, “As far as my principal, he’s 
done a great job just supporting me and ensuring that any of my students, who are getting behind...he has offered moments to get them caught up."

Teacher's felt they could go to other general education teachers, the special education department or administration with questions or concerns that may arise. However, one teacher interviewed did mention communication with the special education teacher for the junior high and high school students could be better. Teachers also mentioned it is important to maintain communication with the parents as well. General education teachers use Class Dojo. With this app, teachers can communicate to parents how the student's day went. Also, teachers make phone calls to parents when issues arise. Administrators interviewed facilitated communication by asking teachers what they needed and making sure they provide support to the general education classroom teacher. From the interview data, administrators expect to see general education teachers communicating with special education teachers. Administrators also collaborate with other districts when problems arise. This networking helps problem solve when concerns arise. Administrators also allow teachers to share professional development with other teachers. One administrator termed this idea as teachers teaching teachers.

Previous research found that collaboration is key in the success of inclusion of students with disabilities in the general education classroom (Shippen, Crites, Houchins, Ramsey \& Simon, 2005, p. 93; LeDoux, Grave, \& Burt, 2012, p. 24). As mentioned, this collaboration would provide an opportunity to resolve concerns that may arise when teaching students with disabilities in the general education classroom (Buli-Holmberg \& Jeyaprathaban, 2016, p. 121). 


\section{Positive Attitude}

The teachers' and administrators' attitude toward including students with disabilities in the general education classroom were overall very positive. Teachers created a welcoming environment for students with disabilities and felt inclusion is a wonderful idea. During teacher observations, the researcher observed general education teachers explaining expectations for the class period. During this explanation, students were instructed what to do if they didn't understand what was going on in the classroom. Teachers explained there were no wrong answers. Teachers encourage student participation from everyone. Teachers want to provide the best education for all students in the district and from the responses given in their interviews are willing to do what is necessary to help students with disabilities be successful. General education teachers seek help when they are unsure how to provide instruction for students with disabilities. Teachers complement students on their participation and validate their responses. Teachers use their relationships with the students to encourage student engagement. Administrators also had very positive attitudes to including students with disabilities in the general education classroom. They are confident the general education environment provides the best learning for students with disabilities. Administrators feel students with disabilities should be learning in the general education environment as much as possible.

Previous research shows teacher attitudes toward inclusion of students with disabilities in the general education classroom plays a significant role in the success of students (Fuchs, 2010, p. 30-31). Academic success is dependent on the attitudes of teachers (Fuchs, 2010, p. 30; Taylor \& Ringlaben, 2012, p. 17). Hwang \& Evans (2011) 
claim general education teachers have more positive than negative attitudes to inclusion, but their willingness to have students with disabilities in their classroom was more negative (p. 27). This opinion differs from the information collected from this case study. I found teachers and administrators are confident that inclusion is a good idea, but teachers and administrators in this school district were also willing to teach students with disabilities in their classroom. Dudley-Marling \& Burns (2014) found that a negative effect will occur when teachers are focusing on accommodating students with disabilities in the general education classroom (p. 20). I did not see this during my research. Teachers and administrators interviewed were prepared to provide the accommodations needed to create academic success for students with disabilities. One reason a positive attitude was noted among general education classroom teacher in this case study could be because the class size is small. A small class size would make it easier to implement accommodations and modifications for students with disabilities in the general education classroom.

\section{Obstacles to Inclusion}

General education teachers mentioned in their interviews, the amount of time needed to work one-on-one with students with disabilities can be an issue. General education interviews discovered students with disabilities sometimes need one-on-one instruction for students to understand curriculum. One general education teacher mentioned, "I feel like I'm running short on time trying to get them [students with disabilities] what they need and then keeping the other kids on track too." Rose (2001) states students with disabilities take more time to plan for and this can take away from the education of non-disabled students (p. 35). The amount of time it takes to make 
modifications for students with disabilities can be difficult. One participant mentioned making modifications for students with disabilities can be an obstacle.

Although the amount of time needed to plan for students with disabilities can be more than that of their non-disabled peers, teachers in the school district under study felt the general education classroom was the best learning environment for students with disabilities.

Administrators interviewed did not mention time as an obstacle, however, manpower was mentioned. One administrator remarked the district has enough teachers, but not enough teachers at the right time. In order to ensure students have what they need, the district pulls from other resources. In addition, one administrator interviewed noted financial resources is an obstacle.

\section{Recommendations}

After reviewing the research collected in this case study, it is clear teachers and administrators in this school district support the idea of inclusion of students with disabilities in the general education classroom. Teachers and administrators have positive attitudes which will increase the success of inclusion in this district. Teachers and administrators communicate and collaborate to ensure the academic success of students with disabilities. Teachers and administrators are willing to take responsibility for their part in ensuring the success of all students.

Teachers and administrators expressed the need for professional development and training for specific strategies to be used when teaching students with disabilities in the general education classroom. Professional development opportunities need to be put in place to increase the knowledge of general education teachers. This professional 
development needs to be continuous and specific to teacher needs. Administrators need to plan professional development opportunities for general education teachers on teaching strategies to instruct students with disabilities in the general education classroom. This professional development can be done as a district or the district can send a few teachers to learning opportunities and those teachers can bring information back to the district and share with their colleagues.

Teachers also need time to collaborate with other teachers. Collaboration time needs to be established to help meet the needs of students and teachers. Collaboration time is essential to providing the best learning environment for students with disabilities. Administrators can add breakout sessions to the professional development provided to the school district. Breakout sessions could provide an opportunity for general education teachers to choose which training best meets their needs. Also, this would allow some time to collaborate with other teachers or special education staff.

\section{Limitations}

Teachers and administrators from one school district were interviewed for this case study. This is a limitation and results may not be generalized to other school districts. In addition, this school district is a small, rural school. Results may not generalize to larger, urban districts. Nine teachers and two administrators were interviewed for this case study. A larger sample population may provide different results.

\section{Conclusion}

This chapter discusses the findings regarding teaching students with disabilities in the general education classroom. Once the data was gathered and coded, several themes developed. The need for professional development and additional training was prevalent 
from the data collected. Teachers and administrators feel they would benefit from professional development. Teachers would like additional training on specific strategies to help students with disabilities be successful in the general education classroom and administrators would like additional training on how to help teachers facilitate inclusion of students with disabilities.

This case study showed teachers and administrators provide a safe and supportive environment in which all students can learn. All students need to feel included and should be held to expectations that allow them to be successful in their learning environment. Inclusion of students with disabilities is beneficial to all students.

Teachers and administrators were aware of their responsibilities in teaching students with disabilities. Teachers were knowledgeable of student IEP's. Teachers are providing accommodations and modifications as outlined in these IEP's.

This case study shows teachers and administrators feel students with disabilities should have an equal opportunity to a quality education. Teachers and administrators feel students with disabilities should have access to the same resources as their non-disabled peers. Teachers and administrators feel that diversity is good for all learners.

Communication and collaboration are key in the success of inclusion for students with disabilities. Teachers and administrators agree having collaboration time is essential for student success. Teachers and administrators can help each other with strategies that allow for successful inclusion of students with disabilities.

A positive attitude is crucial when determining the success of inclusion. The teachers and administrators under study expressed very positive attitudes towards students with disabilities in the general education classroom. Teachers and administrators 
are eager to provide the best learning environment to facilitate successful learning for all students.

An additional area discussed was the amount of time needed to plan for students with disabilities. It was noted that teaching students with disabilities in the general education classroom can take more time to plan for. However, general education teachers felt the strategies used for students with disabilities could be useful for other struggling students. 


\section{References}

Adams, M., Bell, L. A., Goodman, D. J., \& Joshi, K. Y. (2016). Teaching for Diversity and Social Justice. New York, NY: Routledge.

Albritton, S., Huffman, S., \& McClellan, R. (2017). A study of rural high school principals' perceptions as social justice leaders. Administrative Issues Journal: Connecting Education, Practice, and Research, 7(1), 19-38. doi:10.5929/2017.7.1.1

Allen, J. G., Harper, R. E., \& Koschoreck, J. W. (2017). Social Justice and School Leadership Preparation: Can We Shift Beliefs, Values, and Commitments? NCPEA International Journal of Educational Leadership Preparation.

Alquraini, T., \& Gut, D. (2012). Critical Componenets of Successful Inclusion of Students with Severe Disabilities: Literature Review. International Journal of Special Education, 27(1), 42-59.

Aron, L., \& Loprest, P. (2012). Disability and the Education System. The Future of Children, 22(1), 97-122. Retrieved from www.futureofchildren.org

Au, K. H. (1998). Social Constructivism and the School Literacy Learning of Students of Diverse Backgrounds. Journal of Literacy Research, 30(2), 297-319.

Avramidis, E., Bayliss, P., \& Burden, R. (2000). A Survey into Mainstream Teachers' Attitudes Towards the Inclusion of Children with Special Educational Needs in the Ordinary School in one Local Education Authority. Educational Psychology, 20(2), 191-211.

Bartolome, L. I. (2001). Critical Pedagogy and Teacher Education: Radicalizing Prospective Teachers. Teacher Education Quarterly, 97-122. 
Becker, S., \& Polladino, J. (nd). Assessing Faculty Pespectives About Teaching and Working with Students with Disabilities. Journal of Postsecondary Education and Disability, 25(1), 65-82.

Bicehouse, V., \& Faieta, J. (2017). IDEA At Age Forty: Weathering Common Core Standards and Data Driven Decision Making. Contemporary Issues in Education Research, 10(1).

Brackenreed, D., \& Barnett, J. (2006). Teacher Stress and Inclusion: Perceptions of Preservice Teachers. Developmental Disabilities Bulletin, 34(1 \& 2), 156-176.

Braunsteiner, M.-L., \& Mariano-Lapidus, S. (2014). A Perspective of Inclusion: Challenges for the Future. Global Education Review, 1(1), 32-43.

Brenner, D. (2016). Rural Education and the Every Student Succeeds Act. The Rural Educator, 23-27.

Buli-Holmberg, J., \& Jeyaprathaban, S. (2016). Effective Practice In Inclusive and Special Needs Education. International Journal of Special Education, 31(1), 119134.

Bursa, S., \& Erosy, A. F. (2016). Social Studies Teachers' Perceptions and Experiences of Social Justice. Eurasian Journal of Educational Research(64), 319-340.

Cambron-McCabe, N., \& McCarthy, M. M. (2005). Educating School Leaders for Social Justice. Educational Policy, 19(1), 201-222.

Carson, C. (2015). Rethinking Special Education's "Least Restrictive Environment: Requirement." Michigan Law Review, 113, 1397-1426. 
Cate, I. M., Markova, M., Krischler, M., \& Krolak-Schwerdt, S. (2018). Promoting Inclusive Education: The Role of Teachers' Competence and Attitudes. Insights into Learning Disabilities, 15(1), 49-63.

Cathy LeDoux, M. E. (2012). Meeting the Needs of the Special Education Students in Inclusion Classrooms. The Journal of the American Academy of Special Education Professionals, 20-34.

Cherian, F. (2007). Learning to Teach: Teacher Candidates Reflect on the Relational, Conceptual, and Contextual Influences of Responsive Mentorship. Canadian Journal of Education, 30(1), 25-46.

Cho, H. (2017). Navigating the Meanings of Social Justice, Teaching for Social Justice, and Multicultural Education. International Journal of Multicultural Education, 19(2), 1-19.

Cochran-Smith, M. (2003). The Multiple Meanings of Multicultural Teacher Education: A Conceptual Framework. Teacher Education Quarterly, 7-26.

Congressional Digest. (2018). Retrieved from www.congressionaldigest.com.

Costello, S., \& Boyle, C. (2013). Pre-service Secondary Teachers' Attitudes Towards Inclusive Education. Australian Journal of Teacher Education, 38(4), 129-143. Retrieved from http://ro.ecu.edu.au/ajte/vol38/iss4/8

Creswell, J. W. (2009). Research Design Qualitative, Quantitative, and Mixed Methods Approaches. Thousand Oaks, California: SAGE Publications.

Darrow, A.-A. (2009). Barriers to Effective Inclusion and Strategies to Overcome Them. General Music Today, 22(3), 29-31. 
DeJarnett, N. K. (n.d.). Changing Perceptions of Teacher Candidates in High-Needs Schools. School-University Partnerships, 9(1), 71-79.

DeMatthews, D., \& Mawhinney, H. (2014). Social Justice Leadership and Inclusion: Exploring Challenges in an Urban District Struggling to Address Inequities. Educational Administration Quarterly, 844-881.

Department of Elementary and Secondary Education. (2018). Retrieved from www.dese.mo.gov.

DeSimone, J. R., Maldonado, N. S., \& Rodriguez, M. V. (2013). Attitudes about Inclusion: Through the Lens of Practitioners and Novices. Journal of Special Education Apprenticeship, 2(1), 1-16.

Dudley-Marling, C., \& Burns, M. B. (2014). Two Perspectives on Inclusion in the United States. Global Education Reivew, 1(1), 14-31.

Frederick, M. L., Courtney, S., \& Caniglia, J. (2014). With a Little Help from My Friends: Scaffolding Techniques in Problem Solving. The Research Council on Mathematics Learning, 7(2), 21-32.

Fuchs, W. W. (2009-2010). Examining Teachers' Perceived Barriers Associated with Inclusion. SRATE Journal, 19(1), 30-35.

Galvan, J. L. (2013). Writing Literature Reviews (Fifth Edition ed.). California, United States of America: Pyrczak Publishing.

Gilham, C. M., \& Tompkins, J. (2016). Inclusion Reconceptualized: Pre-service Teacher Educaiton and Disability Studies in Education. Canadian Journal of Education, 39(4), 1-25. Retrieved from www.cje-rce.ca 
Gordon, S. P. (2012). Beyond Convention, Beyond Critique: Toward a Third Way of Preparing Educational Leaders to Promote Equity and Social Justice. National Council of Professors of Educational Administration, 1-24. Retrieved from http://cnx.org/content/col11434/1.2/

Hadadian, A., \& Chiang, L. (2007). Special Education Training and Preservice Teachers. International Journal of Special Education, 22(1), 103-106.

Hatch, J. A. (2002). Doing Qualitative Research in Education Settings. Albany, NY: State University of New York Press, Albany.

Hicks-Monroe, S. L. (2001). A Review of Research on the Educational Benefits of the Inclusive Model of Education for Special Education Students. Journal of the American Academy of Special Education Professionals, 61-69.

Hwang, Y.-S., \& Evan, D. (2001). Attitudes Towards Inclusion: Gaps Between Belief and Practice. International Journal of Special Education, 26(1).

Hytten, K., \& Bettez, S. C. (2011). Understanding Education for Social Justice. Educational Foundations, 7-24.

Jorgensen, C. M., \& Lambert, L. (2012). Inclusion Means More that Just Being "In": Planning Full Particiaption of Students with Intellectual and other Developmental Disabilities in the General Education Classroom. International Journal of Whole Schooling, 8(2), 21-35.

Karten, T. J. (2005). Inclusion Strategies That Work! Research-Based Methods for the Classroom. Thousand Oaks: Corwin Press.

Keogh, B. K. (2007). Celebrating PL 94-142: The Education of All Handicapped Children Act of 1975. Issues in Teacher Education, 16(2), 65-69. 
Koseki, M. H. (2017). Meeting the Needs of All Students: Amending the Idea to Support Special Education Students From Low-Income Households. Fordham Urbal Law Journal, 44(3), 793-832.

Kosko, K. W., \& Wilkins, J. L. (2009). General Edcators' In-Service Training and Their Self-Preceived Ability to Adapt Instruction for Students with IEP's. The Professional Educator, 33(2), n. d.

Lambert, L. (n. d.). Inclusive Education. Journal of the American Academy of Special Education Professionals, 67-71.

LaVergne, D. D., Larke, Jr., A., Elbert, C. D., \& Jones, W. A. (2011). The Benefits and Barriers Toward Diversity Inclusion Regarding Agricultural Science Teachers in Texas Secondary Agricultural Education Programs. Journal of Agricultural Education, 140-150.

Lawrence-Brown, D. (2004). Differentiated Instruction: Inclusive Strategies For Standards-Based Learning That Benefit The Whole Class. American Secondary Education, 34-62.

Leafstedt, J. M., Itkonen, T., Arner-Costello, F., Hardy, A., Korenstein, B., Medina, M., . . Regester, A. (2007). "Was It Worth It? You Bet": The Impact of PL 94-142 on Lives and Careers. Issues in Teacher Education, 16(2), 19-31.

Leatherman, J. M. (2007, December). "I Just See All Children as Children": Teachers' Perceptions About Inclusion. The Qualitative Report, 12(4), 594-611. Retrieved from http://www.nova.edu/ssss/QR/QR12-4/leatherman.pdf 
LeDoux, C., Graves, S. L., \& Burt, W. (2012). Meeting the Needs of Special Education Students in Inclusion Classrooms. Journal of the American Academy of Special Education Professionals, 20-34.

Lee, R. E., Creasey, G., Showalter, B. D., \& D'Santiage, V. (2010). Cognitive Development of Social Justice through Re-Designed Courses and CommunityBased Partnerships: An Initial Investigation. Prespectives on Urban Education, 29-34.

Lee, Y. A. (2011). What Does Teaching for Social Justice Mean to Teacher Candidates? The Professional Educator, 35(2), np.

Loewen, G., \& Pollard, W. (2010). The Social Justice Perspective. Journal of Postsecondary Education and Disability, 5-18.

Loreman, T., Sharma, U., \& Forlin, C. (2013). Do Pre-service Teachers Feel Ready to Teach in Inclusive Classrooms? A Four Country Study of Teaching Self-efficacy. Australian Journal of Teacher Education, 38(1), 27-44. Retrieved from http://ro.ecu.edu.au/ajte/vol38/iss1/3

Marshall, C. (2004). Social Justice Challenges to Educational Administration: Introduction to a Special Issue. Educational Administration Quarterly, 40(1), 313. doi:10.1177/0013161X03258139

Martin, E. W., Martin, R., \& Terman, D. L. (1996). The Legislative and Litigation History of Special Education. The Future of Children, 6(1), 25-39.

Mathis, W. J., \& Trujillo, T. M. (2016). Lessons from NCLB for the Every Student Succeeds Act. National Education Policy Center, 3-26. Retrieved from http://nepc.colorado.edu/publication/lessons-from-NCLB 
McGovern, M. (2015). Least Restrictive Environment: Fulfilling The Promises of IDEA. Widener Law Review, 21, 117-137.

McKenzie, K. B., \& Scheurich, J. J. (2004). Equity Traps: A Useful Construct for Preparing Principals to Lead Schools That Are Successful With Racially Diverse Students. Educational Administration Quarterly, 40(5), 601-632. doi:10.1177/0013161X04268839

Meister, S. M., Zimmer, W. K., \& Wright, K. L. (2017). Social Justice in Practitioner Publications: A Systematic Literature Review. Journal of Urban Learning, Teaching \& Research, 90-111.

Mitchel, R. E., Goodyear, R. K., Gragg, J. B., Mirci, P. S., \& Morgan, R. (2016). School Setting Behavior That Characterizes Social Justice: An Empirical Approach to Illustrate the Concept. American Educational Research Association, 2(3), 1-16.

Moore-Gumora, C. (2014). A Study of Students on the Autism Spectrum Transformation in a High School Transition Program. Educational Leadership and Administration: Teaching and Program Development, 25, 77-91.

Morgan, J. L. (2016). Reshaping the Role of a Special Educator into a Collaborative Learning Specialist. International Journal of Whole Schooling, 12(1), 40-60.

Murray, O. (2010). A Mindfulness To Transcend Pre-Service Lip-Service A Call for k-12 Schools to Invest in Social Justice Education. Multicultural Education, 48-50.

Obiakor, F. E., Harris, M., Mutua, K., Rotatori, A., \& Algozzine, B. (2012). Making Inclusion Work in General Education Classrooms. Edcucation and Treatment of Children, 35(3), 477-490. 
Ochoa, T. A., Erden, E., Alhajeri, O., Hurley, E., Lee, K., Ogle, L., \& Wang, T. (2017). DIsability Laws and Special Education Provisions in China, Kuwait, South Korea, Turkey, and the United States. International Journal of Special Education, 32(2), $325-354$.

Palincsar, A. S. (1998). Social Constructivist Perspectives on Teaching and Learning. Annu. Rev. Psychol., 49, 345-375.

Palladino, S. B. (no year). Assessing Faculty Perspectives About Teaching and Working with Students with Disabilities. Journal of Postsecondary Education and Disability, 29(1), 65-82.

Penuel, W., Meyer, E., \& Valladares, M. R. (2016, November). Making the Most of the Every Student Succeeds Act (ESSA) - Helping States Focus on School Equity, Quality and Climate. National Education Policy Center, 1-12. Retrieved from http://nepc.colorado.edu/publication/ESSA

Picower, B. (2007). Supporting New Educators to Teacher for Social Justice: The Critical Inquiry Project Model. Penn GSE Perspectives on Urban Education, 1-22. Retrieved from http://www.urbanedjournal.org

Pinto, L. E., Portelli, J. P., Rottmann, C., Pashby, K., Barrett, S. E., \& Mujuwamariya, D. (2012). Social Justice: The Missing Link in School Adminstrators' Perspectives on Teacher Induction. Canadian Journal of Educational Administration and Policy, 1-21.

Pivik, J., McComas, J., \& LaFlamme, M. (2002). Barriers and Facilitators to Incusive Education. Exceptional Children, 69(1), 97-107. 
Portelli, J. P., \& Koneeny, P. (2018, April). Inclusive Education: Beyond Popular Discourses. International Journal of Emotional Education(133-144). Retrieved from www.um.edu.mt/ijee

Rebore, R. W. (n.d.). Faculty Leadership in Implementing Public Law 94-142. Education, 100(4), 395-397.

Reyes, M. E., Hutchinson, C. J., \& Little, M. (2017). Preparing Eduators to Teach Effectively in Inclusive Settings. SRATE Journal, 26(1), 21-29.

Rust, F., \& Bergey, N. (2014). Developing Action-Oriented Knowledge among Preservice Teachers: Exploring Learning to Teach. Teacher Education Quarterly, 63-83.

Ryan, J. (2006). Inclusive Leadership and Social Justice for Schools. Leadership and Policy in Schools, 3-17.

Schultz, E. K., \& Simpson, C. G. (2013). Factors Influencing Teacher Behavior with Students with Diverse Learning and Behavioral Needs. Journal of the America Academy of Special Education Professionals, 118-131.

Sharp, L. A. (2016). ESEA Reauthorization: An Overview of the Every Student Succeeds Act. Texas Jouranl of Literacy Education, 4(1), 9-13.

Shippen, M. E., Crites, S. A., Houchins, D. E., Ramsey, M. L., \& Simon, M. (2005). Preservice Teachers' Perceptions of Including Students with Disabilties. Teacher Education and Special Education, 28(2), 92-99.

doi:10.1177/088840640502800202 
Siegel-Hawley, G., \& Frankenberg, E. (2012). Spaces of Inclusion? Teachers'

Perceptions of School Communities with Differing Student Racial \& Socioeconomic Contexts. The Civil Rights Project, 1-60.

Storms, S. B. (2013). Preparing Teachers for Social Justice Advocacy Am I Walking my Talk? Multicultural Education, 33-39.

Strain, L. B. (2006). Documenting Characteristics of Highly Qualified Teahers. Forum on Public Policy, 1-9.

Taylor, R. W., \& Ringlaben, R. P. (2012). Impactice Pre-service Teachers' Attitudes Toward Inclusion. Higher Education Studies, 2(3), 16-23. doi:10.5539/hes.v2n3p16

U.S. Department of Education. (2018). Retrieved from www.ed.gov.

VanSciver, J. H., \& Conover, V. A. (2009). Making Accommodations Work for Students in the Special Education Setting. TEACHING Exceptional Children Plus, 5(2), 210.

Villegas, A. M. (2007). Dispositions in Teacher Education: A Look At Social Justice. Journal of Teacher Education, 58(5), 370-380. doi:10.1177/0022487107308419

Wang, F. (2017). Social Injustices in Schools: Principals' Percpetion. Values and Ethics in Educational Administration, 1-9.

Wright, P. W., \& Wright, P. D. (2016). Special Education Law (2nd ed.). VA: Harbor House Law Press.

Yell, M. L., Rogers, D., \& Rogers, E. L. (1998, July 1). The Legal History of Special Education: What a Long, Strange Trip It's Been! Remedial and Special Education, 19(4), 219-228. doi:10.1177/074193259801900405 
Zhang, Y., Goddard, J. T., \& Jakubiec, B. A. (2018). Social Justice Leadership in Education: A Suggested Questionnaire. Research in Educational Administration and Leadership, 53-85. 


\section{Appendix A: Special Education Placement}

\section{Special Education Placements}

\section{Early Childhood Placement Options}

\section{Early Childhood Setting}

Children with disabilities who receive all of their special education and related services in educational programs designed primarily for children without disabilities. No education or related services are provided in separate special education settings.

Early Childhood Special Education Setting Children with disabilities who receive all of their special education and related services in educational programs designed primarily for children with disabilities housed in regular school buildings or other community-based settings. No education or related services as designated by an IEP are provided in early childhood settings.

\section{Home}

Children with disabilities who receive all of their special education and related services in the principal residence of the child's family or caregivers.

\section{Part Time EC/Part time ECSE Setting}

Children with disabilities who receive all of their special education and related services in multiple settings, such that: (1) general and/or special education and related services are provided at home or in educational programs designed primarily for children without disabilities, AND (2) special edueation and related services are provided in programs designed primarily for children with disabilities.

\section{Residential Facility}

Children with disabilities who receive all of their special education and related services in publicly or privately operated residential schools or residential medical facilities on an inpatient basis.

Separate School

Children with disabilities who receive all of their special education and related services in educational programs in public or peivate day schools specifically for children with disabilities.

\section{Itinerant Service Outside the Home}

Children with disabilities who receive all of their special education and related services at a school, hospital facility on an outpatient basis, or other location for a short period of time (i.e., no more than 3 hours per week). (This does not include children receiving services at home.) These services may be provided individually or to a small group of children.

\section{Kindergarten - Grade 12 Placement Continuum}

Inside the Regular Class $\mathbf{8 0}$ percent or more of the day Students with disabilities who are inside the regular classroom for 80 percent or more of the school day. (These are children who receive special education and related services outside the regular classroom for less than 21 percent of the school day.) This may apply to children with disabilities placed in:

- regular class with special education/related services provided within regular classes;

- regular class with special education/related services provided outside regular classes; or

- regular class with special education services provided in resource rooms.

Inside regular class no more than $79 \%$ of day and no less than $40 \%$ percent of the day

Students with disabilities who are inside the regular classroom between 40 and $79 \%$ of the day. (These are children who received special education and related services outside the regular classroom for at least 21 percent but no more than 60 percent of the school day.) This does not apply to children who are receiving education programs in public or private separate school or residential facilities. This may apply to children placed in:

- resource rooms with special education/related services provided within

the resource room; or

- resource rooms with part-time instruction in a regular class.

Inside regular class less than 40 percent of the day Students with disabilities who are inside the regular classroom less than 40 percent of the day. (These are children who received special education and related services outside the regular classroom for more than 60 percent of the school day.) This does not apply to children who are receiving education programs in public or private separate school or residential facilities. This category may apply to children placed in:

- self-contained special classrooms with part-time instruction in a regular class; or

- self-contained special classrooms with full-time special education instruction on a regular school camnus.

Public Separate (Day) Facility

Children with disabilities who receive all of their special education and related services for greater than 50 percent of the school day in public separate facilities for children with disabilities.

\section{Private Separate (Day) Facility}

Children with disabilities who receive all of their special education and related services, at public expense, for greater than 50 percent of the school day in private separate facilities for children with disabilities

Public Residential Facility

Children with disabilities who receive all of their special education and related services for greater than 30 percent of the school day in public residential facilities.

Private Residential Facility

Children with disabilities who receive all of their special education and related services, at public expense, for greater than 50 percent of the school day in private residential facilities.

\section{Homebound/Hospital}

Children with disabilities who receive all of their special education and related services in hospital programs or homebound programs. 
Appendix B: Types of Resources for Extra Support

\section{Types of Resources for Extra Support}

Manipulatives- e.g., students can use cubes representing the base-10 number system to create models and solve problems concretely. Because they denote the base-10 system, even complex problems can be modeled using this approach. Transparent cubes are available for use with an overhead projector.

Visual aids - e.g., diagrams, models, story maps, etc.

Charts - e.g., when memorization is needed, students create their own charts to allow them to look up facts that they've not yet memorized (as opposed to practices incorrect answers).

Outlines - summaries, organizers, and reading guides. For example, when the textbook is beyond the student's reading level, 1-2 page chapter summaries that highlight the most important information and area written at the student's reading level can be provided. To help ensure a match between students' reading levels and reading materials, word processing programs can provide reading level estimates of text. For nonreaders, summaries can be audio taped or accessed using screen reading software. Picture cues - e.g., combining vocabulary words with graphics and other illustrations. Audio taped books, instructions, etc.

Lawrence-Brown, D. (2004). Differentiated Instruction: Inclusive Strategies For Standards-Based Learning That Benefit The Whole Class. American Secondary Education, 34-62. 


\section{Appendix C: Classroom Accommodations and Modifications}

Differentiated Instruction refers to adjustments in teaching methods or materials to accommodate each student's learning needs and preferences and is available for all students. These instructional strategies should not be documented on Form F.

Accommodations are changes in procedures or materials that increase equitable access in the classroom setting. Accommodations generate comparable results for students who need them and allow these students to demonstrate what they know and can do. Modifications are changes in procedures or materials that change the construct of the educational task making it difficult to compare results with typical peer results. Modifications allow students to demonstrate what they know and can do in a non-standardized way.

Indicate below the accommodations and modifications for the student to be used in general and/or special education and supports to be provided to school personnel.

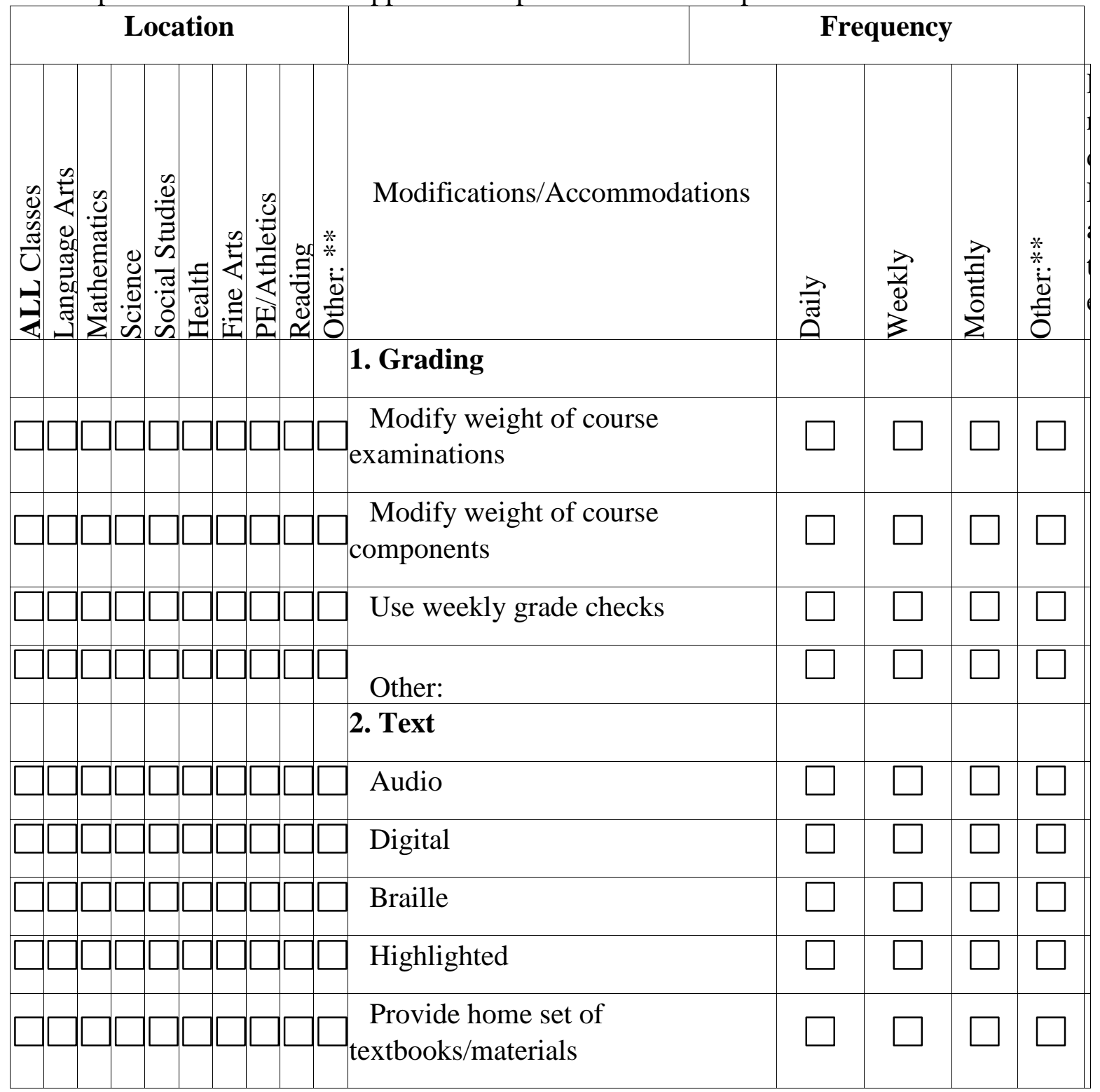




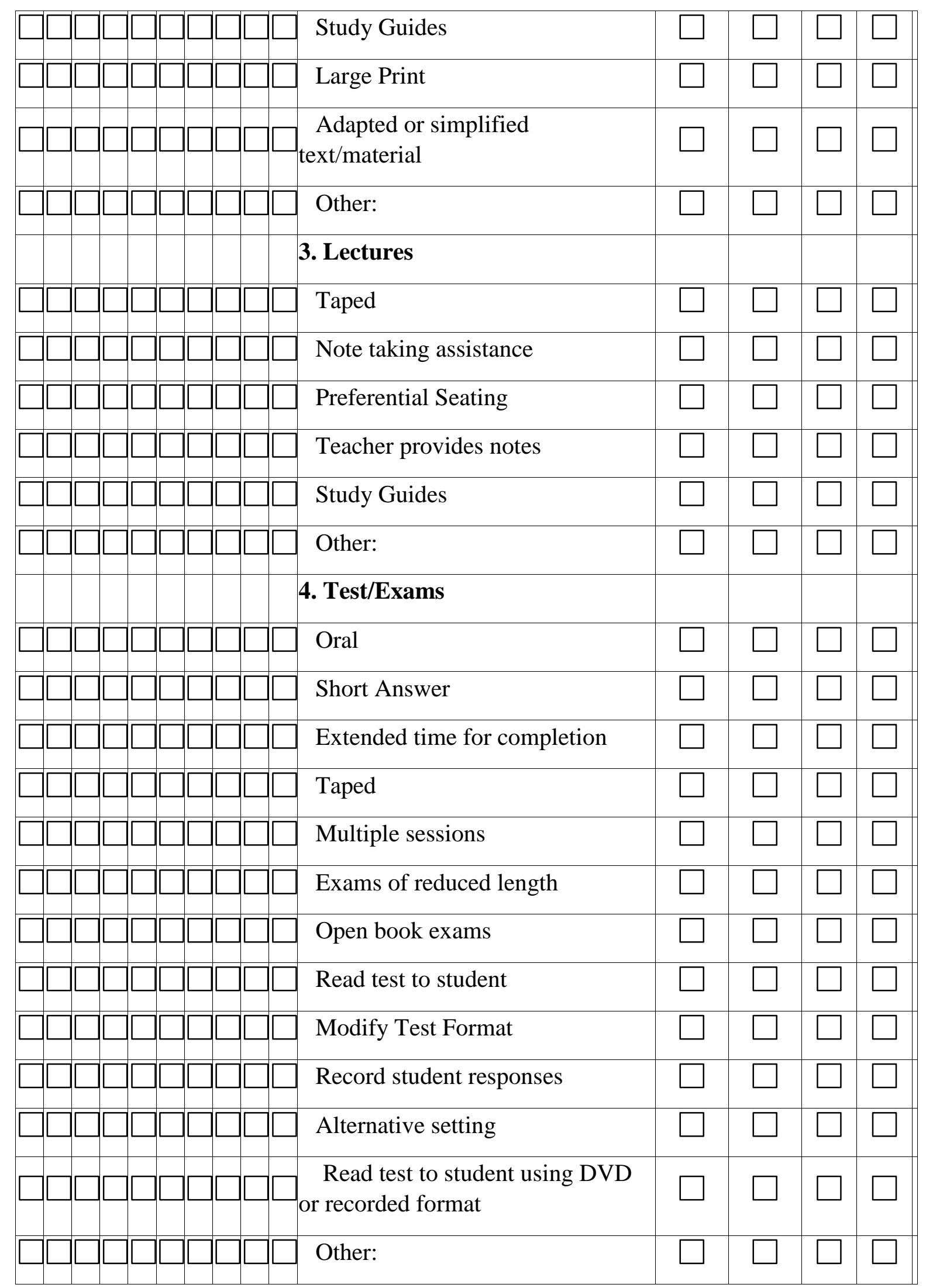




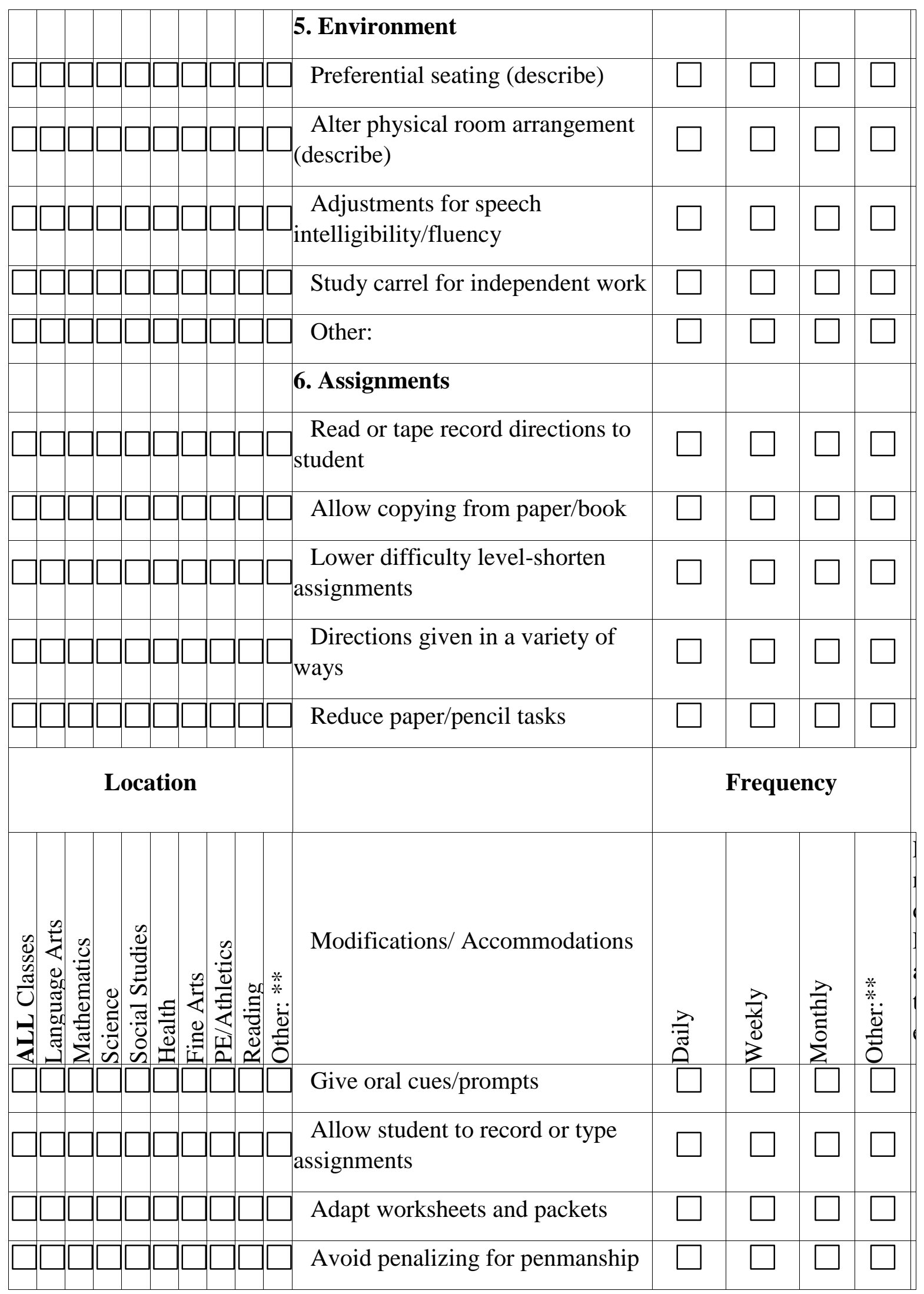




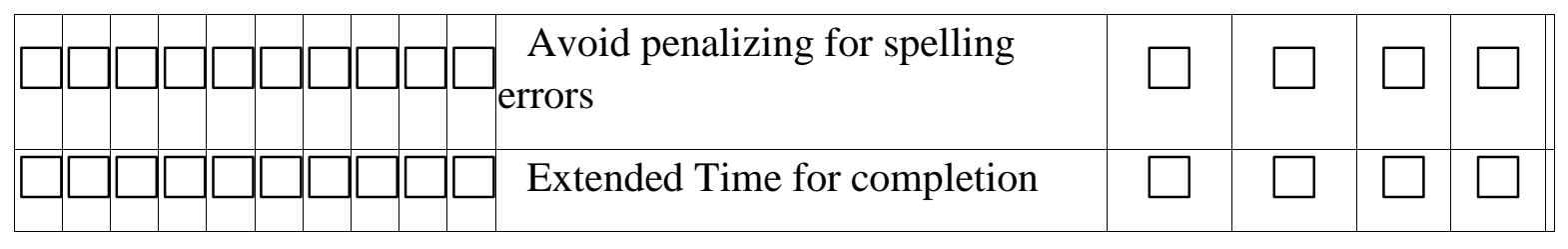

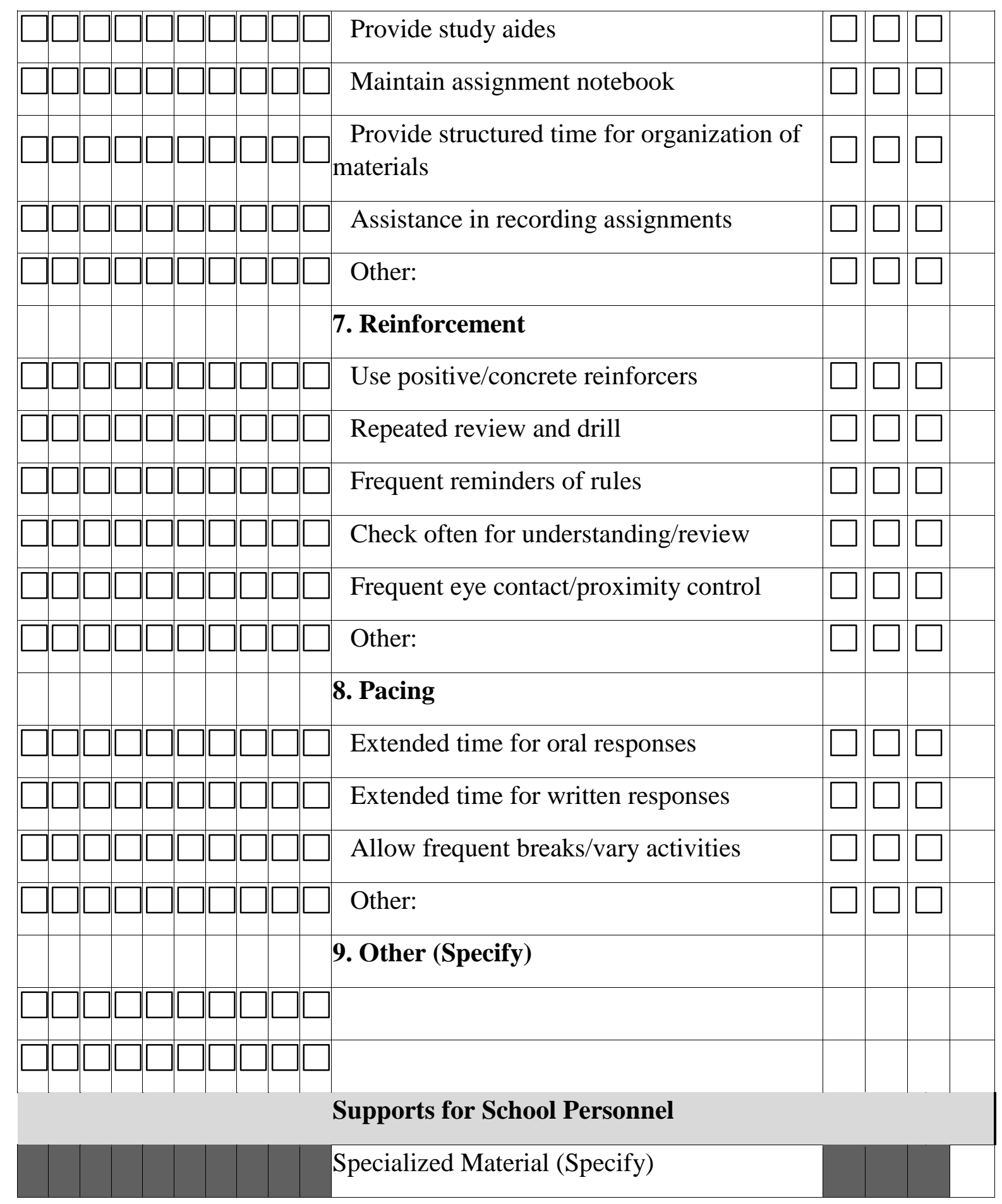




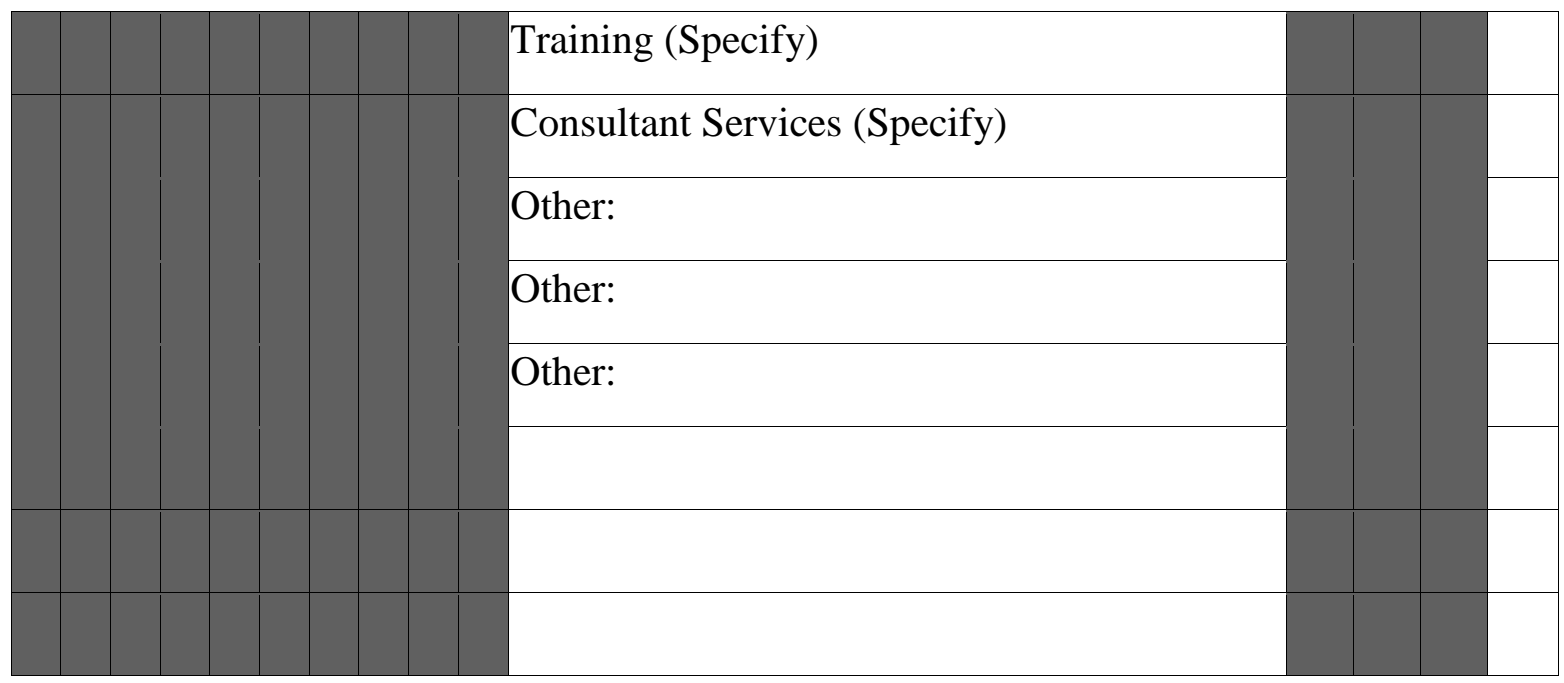

* N/A if will be same as initiation and annual review date indicated on page 1. If a date is listed, it must include the month, day, and year.

** Must describe "Other"

\begin{tabular}{|l|l}
\hline For LOCATION: & For FREQUENCY:
\end{tabular} 


\section{Appendix D: Interview Protocol for the Classroom Educator}

Researcher: Thank you for taking time to help in this research study. The following questions are related to your perspectives regarding inclusion of students with disabilities in the general education classroom. There are no right or wrong answers. All information will be kept confidential. The researcher will be the only one with access to identifiable information.

Date of Interview:

Location of Interview:

\section{Questions:}

1. What is your current position in the school district?

2. How many years have you been at your current position?

3. How many years have you been with the school district?

4. What is your educational level? 
5. Please describe your thoughts about inclusion of students with disabilities in the general education classroom?

6. Please describe how your educational background has prepared you to teach students with disabilities?

7. How confident are you in your abilities to teach students with disabilities?

8. Please describe how you would benefit from professional development regarding teaching strategies for students with disabilities?

9. Please describe how you would implement the information from professional development in your classroom? 
10. Please describe your role as a general education teacher in respect to teaching students with disabilities?

11. Please describe how you foster an environment that allows for diversity within your classroom?

12. Please describe any obstacles to teaching student with disabilities in your classroom?

13. Please describe the level of support from other colleges? From administrators? 
Appendix E: Interview Protocol for the School District Administrator

Researcher: Thank you for taking time to help in this research study. The following questions are related to your perspectives regarding inclusion of students with disabilities in the general education classroom. There are no right or wrong answers. All information will be kept confidential. The researcher will be the only one with access to identifiable information.

Date of Interview:

Location of Interview:

Questions:

1. What is your current position in the school district?

2. How many years have you been at your current position?

3. How many years have you been with the school district?

4. What is your educational level? 
5. Please describe your thoughts about inclusion of students with disabilities in the general education classroom

6. Please describe your role in facilitating inclusion/full inclusion in the school district?

7. Please describe your role in facilitating professional development opportunities for teachers who struggle teaching students with disabilities?

8. Please describe how professional development shows in the classroom?

9. What support role do you provide to your staff when implementing inclusion of students with disabilities in the general education classroom? 
10. Please describe obstacles to teaching student with disabilities in your building?

11. Please provide your thoughts on why inclusion is important?

12. What do you expect to see from teachers in an inclusive classroom? 
Appendix F: Participant Request

INCLUSION OF SPECIAL NEEDS STUDENTS IN THE GENERAL EDUCATION CLASSROOM

Your participation is requested for research study for an individual dissertation.

Please read the following information which discusses the reason behind the research and what your participation involves. You may contact me for further clarification or questions. My contact information is at the end of this document.

WHO I AM AND WHAT THIS STUDY IS ABOUT

My name is Kimberly Kesler. I am currently a special education director and teacher at a small, rural Southeast Missouri school. I am currently completing the requirements for the Ed.D. program for Educational Policy and Leadership Analysis associated with the University of Missouri. As the director of special education, making sure students with disabilities are receiving a fair and equal education is one of my job responsibilities.

A goal to this research is to understand teacher and administrators' perspectives of inclusion for students with disabilities in the general education classroom. It is important to develop this understanding to provide the best education for all students. This research will serve as evaluation to how teacher's and building administrators perceive inclusion of students with disabilities is currently being employed in their school district. This study is an inquiry into the perceptions of current teachers and administrators. There are not right or wrong answers.

\section{WHAT WILL MY INVOLVEMENT INCLUDE?}

To gain insight to teacher and administrator perspectives, participants will be asked to take part in a one-to-one interview with the researcher. Teachers and 
administrators will be asked questions regarding their role in inclusion for students with disabilities, as well as, any obstacles that may prevent inclusion of students with disabilities in the general education classroom. The interviews will take approximately 30 minutes and they will be done at a location chosen by the interviewee. In addition, some participants will be asked to take part in an observation of the classroom routine. The researcher will observe the general education teacher at a time of their choosing. The observations will take approximately 30 minutes.

\section{WHY HAD YOU BEEN INVITED TO TAKE PART}

You are a teacher or administrator in the district under study. You can provide valuable information regarding inclusion of student with disabilities in the general education classroom.

\section{DO YOU HAVE TO PARTICIPATE}

While your participation in this case study is entirely voluntary, the information you will provide is tremendously valuable. You may refrain from answering any questions and you may exit the research study at any time.

\section{WHAT ARE THE POSSIBLE RISKS AND BENEFITS OF PARTICIPATION}

The risks and benefits of participation in this case study are minimal. No identifiable information will be used in the research. The researcher is the only one with access to identifiable information. All information collected will be stored and keep in a secure place offsite. All teacher and administrator interviews will be conducted in a impartial location chosen by the interviewee. All data collected will be made available to the participants. The information collected will allow themes and generalizations 
regarding the perspectives of inclusion of students with disabilities in the school district to be evaluated.

\section{HOW WILL THE INFORMATION PROVIDED BY COLLECTED AND STORED}

The researcher will use an audio device to record the information gathered during the interview process. All information collected will be stored on the researcher's personal computer. After the information is transcribed, the audio recording will be destroyed. All information will be printed and kept in locked storage at the researcher's personal residence. The researcher will be the only one with access to the information collected.

\section{WHAT WILL HAPPEN TO THE RESULTS OF THIS STUDY}

The information collected is done to meet the requirements of a doctorate degree. There is not intent to publish the research results. The information may be shared with the school district at their request, however, no identifiable information will be included in the results.

\section{WHO SHOULD BE CONTACTED FOR FURTHER INFORMATION}

Kimberly Kesler, Researcher 573.380.1636

Kimberlykesler1990@gmail.com

Paul Watkins, Faculty Supervisor

pwatkins@semo.edu

Thank you,

Kimberly Kesler 


\section{VITA}

Kimberly Kesler was born, Kimberly Dawn Austin, in St. Louis, MO on September 25, 1972. She attended Kindergarten and First Grade in the St. Louis area. Kimberly's parents divorced when she was eight years old. She moved to the Southeast Missouri area with her mother and attended a small, rural school from $3^{\text {rd }}$ grade through $12^{\text {th }}$ grade.

After graduating high school, Kimberly attended Southeast Missouri State University where she graduated with a Bachelor of Science in Psychology in 1995. That same year, she married her husband of 24 years. The couple have two children. In 2007, Kimberly attained her Missouri teaching certification for Mild to Moderate Cross Categorical K-12. She worked as a special education aid for a year and then became the lead teacher for a Junior High special education classroom. After two years as a Junior High Special Education Teacher, Kimberly began teaching elementary special education. She has been a special education teacher for 17 years.

In 2009, Kimberly earned her Master of Educational Administration through William Woods University. In 2011, she began her doctoral coursework from the University of Missouri. In 2017, Kimberly assumed the role of Special Education Director. Currently Kimberly is a Special Education Teacher for grades K-2 and Special Education Director for a small, rural school in Southeast Missouri. 